NBER WORKING PAPER SERIES

THE MACROECONOMICS OF MICROFINANCE

Francisco J. Buera

Joseph P. Kaboski

Yongseok Shin

Working Paper 17905

http://www.nber.org/papers/w17905

\author{
NATIONAL BUREAU OF ECONOMIC RESEARCH \\ 1050 Massachusetts Avenue \\ Cambridge, MA 02138 \\ March 2012
}

The views expressed herein are those of the authors and do not necessarily reflect the views of the National Bureau of Economic Research. Buera and Shin gratefully acknowledge the financial support of the National Science Foundation (SES-0946647) and the Consortium on Financial Systems and Poverty at the University of Chicago. Kaboski gratefully acknowledge the Consortium on Financial Systems and Poverty at the University of Chicago for financial support.

NBER working papers are circulated for discussion and comment purposes. They have not been peerreviewed or been subject to the review by the NBER Board of Directors that accompanies official NBER publications.

(C) 2012 by Francisco J. Buera, Joseph P. Kaboski, and Yongseok Shin. All rights reserved. Short sections of text, not to exceed two paragraphs, may be quoted without explicit permission provided that full credit, including $\odot$ notice, is given to the source. 
The Macroeconomics of Microfinance

Francisco J. Buera, Joseph P. Kaboski, and Yongseok Shin

NBER Working Paper No. 17905

March 2012

JEL No. D91,D92,E44,O11

\begin{abstract}
$\underline{\text { ABSTRACT }}$
We provide a quantitative evaluation of the aggregate and distributional impact of microfinance or credit programs targeted toward small businesses. We find that the redistributive impact of microfinance is stronger in general equilibrium than in partial equilibrium, but the impact on aggregate output and capital is smaller in general equilibrium. Aggregate total factor productivity (TFP) increases with microfinance in general equilibrium but decreases in partial equilibrium. When general equilibrium effects are accounted for, scaling up the microfinance program will have only a small impact on per-capita income, because the increase in TFP is counterbalanced by lower capital accumulation resulting from the redistribution of income from high-savers to low-savers. Nevertheless, the vast majority of the population will be positively affected by microfinance through the increase in equilibrium wages.
\end{abstract}

Francisco J. Buera

Department of Economics University of California, Los Angeles

8283 Bunche Hall Office 8357

Mail Stop: 147703

Los Angeles, CA 90095

and NBER

fjbuera@econ.ucla.edu

Joseph P. Kaboski

Department of Economics and Econometrics

University of Notre Dame

434 Flanner Hall

Notre Dame, IN 46556

and NBER

jkaboski@nd.edu
Yongseok Shin

Department of Economics

Washington University in St. Louis

1 Brookings Dr

Saint Louis, MO 63130

yshin@wustl.edu 
Over the past several decades, microfinance - i.e., credit targeted toward small-scale entrepreneurial activities of the poor who may otherwise lack access to financing - has become a pillar of economic development policies. In recent years, there has been a concerted effort to expand such programs with the goal of alleviating poverty and promoting development. ${ }^{1}$ Between 1997 and 2006, access to microfinance grew by up to 29 percent a year, reaching a scale at which macroeconomic considerations become relevant. The Microcredit Summit Campaign as of 2010 reports 3,552 institutions serving 155 million borrowers, which including borrowers and their households affect 533 million people, roughly the size of Latin America. For various countries, microfinance loans represent a significant fraction of their GDP. ${ }^{2}$ Despite the growth and prevalence of microfinance and its importance in academic and policy circles, quantitative analyses of these programs are almost exclusively limited to microevaluations. The macroeconomic effects of economy-wide microfinance have been largely unexplored. ${ }^{3}$

This paper is an attempt to fill that void by providing a quantitative assessment of the potential impact of economy-wide microfinance availability, with particular attention to general equilibrium (GE) effects. We find that the typical microfinance program, when made widely available in an economy, can have significant aggregate and distributional impacts, and that the GE effects through wages and interest rates are quantitatively important.

In partial equilibrium ( $\mathrm{PE})$, microfinance induces a high rate of entry among marginally productive entrepreneurs, increasing the capital/labor demand and output, but lowering the aggregate total factor productivity (TFP). In GE, however, the increase in wage that results from marginal entrepreneurs selecting out of the labor supply - and demanding labor instead - has strikingly different impacts on output, capital, and TFP. In redistributing income away from individuals with high saving rates (high-ability entrepreneurs) to those with low saving rates (marginal entrepreneurs and workers), microfinance leads to lower aggregate saving and capital accumulation. Higher wages and interest rates also lead low-productivity entrepreneurs to exit, and TFP actually increases with microfinance in contrast to the PE result. In net, the lower capital accumulation and higher TFP lead to positive overall impacts on consumption and output, but the magnitudes are substantially smaller than in PE.

\footnotetext{
${ }^{1}$ The United Nations, in declaring 2005 as the International Year of Microcredit, called on a commitment to scaling up microfinance at regional and national levels in order to achieve their Millenium Development Goals. The scaling up of microfinance is usually understood as the expansion of programs providing small loans to reach all the poor population, as opposed to increasing the average size of loans.

${ }^{2}$ Examples are Bangladesh (0.03), Bolivia (0.09), Kenya (0.03), and Nicaragua (0.1), as calculated using loan data from the Microfinance Information Exchange and domestic price GDP from the Penn World Tables.

${ }^{3}$ We note two important exceptions. Ahlin and Jiang (2008), using the model of Banerjee and Newman (1993), derive the theoretical conditions under which microfinance can lead to aggregate development. Kaboski and Townsend (2012) use reduced-form methods to estimate the general equilibrium effects of village banks on wages and interest rates within the village.
} 
More important, our GE results affirm that microfinance is a pro-poor redistributive policy, benefitting the poor-marginal entrepreneurs directly and workers indirectly through higher wages - and potentially hurting the most able and rich entrepreneurs through the higher factor prices.

To develop the analysis, we start from a model of entrepreneurship in which financial development has already been shown to have sizable aggregate impacts (Buera et al., 2011). Individuals choose in each period whether to become an entrepreneur or supply labor for a wage. They have different levels of entrepreneurial productivity and wealth. The former evolves stochastically, generating the need to reallocate capital and labor from previously-productive entrepreneurs to currently-productive ones. Financial frictions - which we model in the form of endogenous collateral constraints founded on imperfect enforceability of contracts - hinder this reallocation process.

Into this environment, we introduce microfinance in a way that captures the narrative of microfinance as credit for entrepreneurial capital. While being agnostic about the underlying innovation behind microfinance, we model it as a financial intermediation technology that guarantees access to - and full repayment of - productive capital up to a limit, regardless of their collateral or entrepreneurial talent. Since we model economy-wide microfinance, everyone has access to it in principle. However, since the wealthy already have access to financing beyond the microfinance limit, only the poor have their choice set expanded by microfinance, and the marginal entrepreneurs - who would have chosen not to run their own business in the absence of microcredit - are affected in the most direct and significant way.

We discipline and validate our quantitative analysis on two fronts. First, we require our model to match data from developed and developing countries on the distribution and dynamics of establishments, and the ratio of external finance to GDP. Second, we ask whether the short-run PE implications of our calibrated model are reasonable by comparing them with the estimates from recent microevaluations of microfinance programs in India (Banerjee et al., 2009), Thailand (Kaboski and Townsend, 2011, 2012), Mongolia (Attanasio et al., 2011), Morocco (Crépon et al., 2011), and the Philippines (Karlan and Zinman, 2010). We find that our model can capture the magnitude of overall credit expansion and the increase in investment and entrepreneurship, including the entry of marginal entrepreneurs. Although our model does not consider consumption loans, and hence underpredicts the increase in consumption, it nevertheless affirms the heterogeneous impact on consumption reported in the microevaluations.

We then use the model to quantify the effect of microfinance on key macroeconomic measures of development - output, capital, TFP, wage, and interest rates - and its distributional consequences. We start with an equilibrium without microfinance, and raise the size of the 
loans guaranteed by microfinance. We first analyze the long-run impacts (i.e., comparisons across steady states) in partial equilibrium, and then contrast them with the corresponding impacts in general equilibrium.

In the long-run PE case, wages and interest rates are held fixed, and we do not require markets to clear. For guaranteed credit limit of one and a half times the annual wage, a typical size of real-world microfinance loans, the aggregate output-gross domestic product, not adjusted for production factors from outside the economy -increases by 30 percent in the long run, driven by an increase in the number of entrepreneurs and capital/labor inputs. TFP actually declines somewhat, reflecting the entry of marginally productive entrepreneurs. Aggregate consumption increases by 10 percent, and the total financial wealth of the economy - which is not equal to the capital stock of the economy-increases by 18 percent.

The long-run GE results are quite different. In order to clear labor markets, wages rise monotonically with the size of microfinance loans, by 5 percent for guaranteed borrowing that is one and a half times the annual wage. This increase is in line with the wage increase empirically observed at village levels in Kaboski and Townsend (2012). The number of entrepreneurs increases by substantially less than in PE (26 percent vs. 77 percent), since the higher wage deters the entry of low-productivity entrepreneurs. TFP rises by 4 percent, with the majority of the gain coming from a more efficient distribution of capital among entrepreneurs (intensive margin) rather than a better selection into entrepreneurship. More important, the higher wage redistributes wealth from higher-ability entrepreneurs with higher saving rates to lower-productivity individuals with lower saving rates. Thus, aggregate saving rates fall, bringing down aggregate capital by 6 percent. With a capital share of 0.3 , this offsets most of the increase in TFP, and output increases by less than 2 percent. The impact is slightly larger in terms of aggregate consumption, 3 percent, since saving rates are lower.

While the aggregate impacts of microfinance on output and consumption are much smaller in GE than in PE, microfinance is even more strongly pro-poor in GE because of the higher wage. The welfare gains for those with essentially zero wealth (the vast majority of the population) are roughly twice as large under general equilibrium, equivalent to 8 percent of their permanent consumption for guaranteed credit of one and a half times the annual wage. Similarly, the welfare gains of low ability agents - those with no intention of becoming entrepreneurs - are equivalent to about 6 percent of permanent consumption, or three times the gains in partial equilibrium. However, the GE effects make the high ability and high wealth entrepreneurs of the economy actually worse off from microfinance, because their entrepreneurial profit falls with the higher factor prices, while the richest individuals benefit 
from the higher interest rate. ${ }^{4}$

In relating our model predictions to the findings from microevaluations, we recognize that empirical studies often emphasize different aspects of the real-world microfinance programs that are not considered in our benchmark model. In response, we work out three alternative modeling assumptions that will be necessary to capture such richness in empirical findings - e.g., the impact of microfinance in rural vs. urban settings. These extensions also provide additional insights into the inner working of the model, and serve as robustness checks. However, they all share the core message of the paper: GE effects are important for understanding the impact of large-scale microfinance interventions.

The first extension is a "small open economy" in which microfinance borrowers do not compete with other borrowers for aggregate capital. This model broadly reproduces the longrun GE results of the benchmark model both quantitatively and qualitatively, including the decline in aggregate capital stock. Although the supply of capital is infinitely elastic, the demand for capital decreases overall: The increased demand for capital from the availability of uncollateralized credit is more than offset by the decreased demand owing to less collateral being accumulated by talented entrepreneurs, which reflects the redistribution of income from high-savers to low-savers through higher wages.

The second extension introduces a negative idiosyncratic shock to labor supply that effectively forces affected individuals, even those with little collateral and low ability, into entrepreneurship. This captures the idea of undercapitalized, low-ability entrepreneurs with few labor market alternatives, and can be useful for studying the impact of microfinance in rural areas, where labor markets are not very developed (Crépon et al., 2011). In the GE version of this model, for microfinance with small loan sizes, most "forced" entrepreneurs max out the microfinance limit, pushing up the interest rate, and hence the capital rental rate, by substantially more than in the benchmark GE case. The most important impact of microfinance here is on aggregate saving. The forced entrepreneurs reduce their saving rates drastically, because the access to uncollateralized financing implies that they need not accumulate collateral any more. Those with marginal entrepreneurial productivity and labor market opportunities also cut their saving rates substantially, because now they will choose to be workers - because of the higher capital rental rate - and do not need collateral. In addition, through the higher capital rental rate, microfinance redistributes income from high-savers (i.e., high-ability entrepreneurs) to low-savers. Overall, aggregate capital declines sharply, by 18 percent for the microfinance loan size that is 1.5 times the annual wage. As a result, aggregate output and the wage fall below their no-microfinance levels, although they eventually recover once we further raise the size of microfinance loans. In terms of welfare,

\footnotetext{
${ }^{4}$ All welfare calculations correctly take into account the transition phase.
} 
the forced entrepreneurs gain the most from microfinance in this environment.

The third extension introduces a sector that requires a large fixed cost for production (i.e., a large-scale sector). This adds another GE effect through the relative price between the large-scale and the small-scale sectors. We find that the aggregate effects of microfinance are nonlinear. For small credit limits (up to 4 times the annual wage), microfinance increases entrepreneurs' entry into the small-scale sector but not the large-scale sector, pushing down the relative price of the small-scale sector good. This negatively affects capital accumulation, because investment goods - produced by the large-scale sector-are now relatively more expensive. However, when the loan sizes are large enough to directly finance entrepreneurship in the large-scale sector, microfinance has significant positive impact on aggregate output, TFP, and even capital.

The rest of the paper is organized as follows. Section 1 provides empirical motivation by summarizing important microfinance programs, reviewing the literature, and documenting empirical evidence for the saving rate heterogeneity that underlies our capital accumulation effect. In Section 2, we develop the model, including the microfinance intervention. Section 3 describes the calibration, short-run PE results, and a comparison of our results with empirical evaluation studies of microfinance programs. We then analyze the long-run PE and GE effects of microfinance in Section 4, and work out extensions. Section 5 concludes.

\section{Empirical Motivation}

This section documents the main characteristics of microfinance and other credit programs targeted toward small-scale entrepreneurs around the world. We also review the existing studies on microfinance, and summarize the empirical literature on the difference in saving rates between entrepreneurs and non-entrepreneurs, which is shown to be an important feature of our model economy.

\section{$1.1 \quad$ Microcredit Programs}

Microfinance programs and other credit programs targeted toward small-scale entrepreneurs are prevalent and still growing fast. The Microcredit Summit Campaign reports 3,552 institutions with loans to 155 million clients throughout the world as of 2010. For comparison, the numbers in 1997 were 618 institutions and 13 million clients. The six-fold increase in the number of institutions and the twelve-fold increase in the number of borrowers over this period certainly overstate the actual growth because of an increase in survey participation, but the growth is still real and dramatic. For example, a single program, the National Bank for Agriculture and Rural Development (NABARD) in India grew from 146,000 to 49 million 
clients over this period. By the same token of incomplete survey participation and coverage, these numbers certainly understate the actual number of institutions and borrowers.

Microloans are, almost by definition, small, and typically relatively short-term (i.e., one year or shorter), and have high repayment rates. A broad vision of the structure of microcredit can be gleaned from the Microfinance Information Exchange (MIX) dataset, which provides comparable data over 1,127 microfinance institutions (MFIs) in 102 countries, totalling 65 billion dollars in outstanding loans and 90 million borrowers in 2009. The average loan balance per borrower is 655 dollars in 2009, but because loans are typically in poor countries, they are equivalent on average to one-fifth of per-capita gross national income. Moreover, since microfinance is often targeted toward the poorer segments of the economy, the average loan amounts to a substantially larger fraction of the income of actual borrowers. The variation in this ratio between the average loan size and per-capita income across institutions is also large, with a standard deviation of 0.84 and a maximum of 4 .

An important achievement of microfinance is its success in providing uncollateralized loans with relatively low default rates. In 2009, only 5 percent of loans were more than 90 days delinquent. ${ }^{5}$

\begin{tabular}{lccccc}
\hline Country & $\begin{array}{c}\text { Fraction of } \\
\text { Borrowers }\end{array}$ & $\begin{array}{c}\text { MF Loans } \\
\text { to GDP }\end{array}$ & $\begin{array}{c}\text { Average } \\
\text { Loan Size }\end{array}$ & $\begin{array}{c}\text { Per-capita } \\
\text { Income }\end{array}$ & $\begin{array}{c}\text { Total Credit } \\
\text { to GDP }\end{array}$ \\
\hline Bangladesh & 0.13 & 0.028 & 112 & 547 & 0.37 \\
Mongolia & 0.13 & 0.129 & 1,393 & 1,410 & 0.62 \\
Peru & 0.11 & 0.041 & 1,590 & 4,658 & 0.21 \\
Bolivia & 0.09 & 0.107 & 1,926 & 1,776 & 0.31 \\
Vietnam & 0.09 & 0.044 & 510 & 1,024 & 1.06 \\
Kenya & 0.04 & 0.036 & 744 & 803 & 0.20 \\
India & 0.02 & 0.003 & 146 & 1,154 & 0.53 \\
\hline Mean & 0.02 & 0.004 & 655 & 3,192 & 0.50 \\
Std. Dev. & 0.03 & 0.020 & 3,192 & 3,071 & 0.30 \\
\hline
\end{tabular}

Table 1: Microfinance Facts from the MIX Data

Table 1 reports various statistics on microcredit for the top five countries in terms of the number of borrowers as a fraction of the population (first column), as well as Kenya, which has the most penetration in Africa, and India, which has the largest absolute number of microfinance clients. For these countries, the expansion of microfinance is reaching highly

\footnotetext{
${ }^{5}$ This number overstates historical default rates, as it partly reflects the impact of the global recession. For instance, the figure for 2008 is 3 percent. There is also significant heterogeneity in delinquency rates across countries. In the MIX data, 10 percent of the countries report less than 1 percent of loans as delinquent, while slightly over 10 percent of the countries report more than 10 percent of loans in this category, with the Central African Republic showing the highest delinquency rate at 24 percent.
} 
significant levels, with up to 13 percent of the population being active borrowers, and the value of total outstanding microfinance loans can be as large as 13 percent of GDP (second column). In Table 1 we also see that the expansion of microfinance is particularly important among the poorest countries (fourth column), where credit markets are very underdeveloped, as measured by the ratio of total credit to GDP (last column).

Nongovernmental organizations (NGOs) and private for-profit institutions play a large role in global microfinance. In the MIX data, NGOs constitute 37 percent of the institutions and reach 30 percent of the borrowers. Private banks make up only 7 percent of the institutions, but, because they are larger, they account for 27 percent of the borrowers and 63 percent of the total value of loans in the data. ${ }^{6}$

Government initiatives in microfinance and other credit programs targeted toward smallscale entrepreneurs are also important, and many of these are not included in the MIX data. We review public programs in India and Thailand. There have been recent microevaluations in these two countries, one evaluating a public intervention (Thailand) and the other private (India).

In India, the banking and credit sector is dominated by state-owned banks. NABARD is the government's rural development bank, which operates through state co-operative banks, state agricultural and rural development banks, regional rural banks, and even commercial banks. A major program of NABARD is the promotion of small-scale Self Help Groups (SHGs) for saving and internal lending. In 2009, 4.2 million credit-linked SHGs had roughly 5.1 billion dollars in outstanding loans, of which 2.7 billion was new loans. We calculate an average loan size of 1,200 dollars, or roughly 104 percent of the Indian per-capita income. In addition, another 80 million dollars went to microfinance institutions. These loans were then distributed to members of the SHGs. Once we incorporate NABARD's numbers into the Indian data in Table 1, the number of borrowers as a fraction of the population in India increases to 6 percent, and the value of outstanding loans is close to 1 percent of GDP.

In addition, Banerjee and Duflo (2008) describe regulations governing all (private and public) banks that stipulate that 40 percent of credit must go toward priority sectorsagriculture, agricultural processing, transportation, and small-scale industries. Large firms (plants and machinery in excess of 10 million rupees in 2000) were excluded from the priority sector. They show that these regulations are indeed binding and even mainstream banks target small borrowers.

\footnotetext{
${ }^{6}$ Non-bank financial institutions, which provide services similar to those of banks but are subject to different regulations, are another important type of MFIs. They account for 36 percent of the institutions, 38 percent of the borrowers, and 21 percent of the loans. They are mostly for-profit entities. Overall, forprofits account for 41 percent of the institutions, 56 percent of the borrowers, and 73 percent of the loans in the MIX data.
} 
Thailand is another country that has had a large, government-sponsored expansion of credit to village banks for microfinance. In 2001, the Thai Million Baht Village Fund program was inaugurated, which offered one million baht (about 25,000 dollars at the time) to each of the nearly 80,000 villages in Thailand, as a seed grant for starting a village lending and saving fund. The 1.5 billion dollars was tantamount to about 1.5 percent of the Thai GDP at the time. Loans were typically made without collateral, up to 1,250 dollars, but most loans were annual loans of about 500 dollars, or 40 percent of the per-capita income at the time. Kaboski and Townsend (2011) show that borrowing limits varied by village size, and they estimate that the program allowed households to borrow up to 91 percent of annual household income in the smallest villages. The experience of the funds also varied, but typically showed high repayment rates (97 percent) over several years. These funds were evaluated, and successful funds were offered to leverage their capital through loans of up to an additional one million baht from the Government Savings Bank and the Bank of Agriculture and Agricultural Cooperatives, becoming true village banks. In addition, the Bank of Agriculture and Agricultural Cooperatives and the Government Savings Bank, a more urban bank, channel credit toward lower-income borrowers, and all financial institutions are required to hold a minimum amount of assets in these two public banks, providing an implicit subsidy. The former was an early pioneer in joint liability lending, while the latter claims to be one of the largest microfinance institutions in the world.

\subsection{Existing Literature}

A theoretical literature has emphasized the aggregate and distributional impacts of financial intermediation in models of occupational choice and financial frictions (Banerjee and Newman, 1993; Aghion and Bolton, 1997; Lloyd-Ellis and Bernhardt, 2000; Erosa and Hidalgo Cabrillana, 2008). In these studies, improved financial intermediation leads to more entry into entrepreneurship, higher productivity and investment, and a general equilibrium effect that increases wage. It is shown that the distribution of wealth and often the joint distribution of wealth and productivity are critical.

A related literature has found the impacts of better financial intermediation in these models on aggregate productivity and income to be sizable (Giné and Townsend, 2004; Jeong and Townsend, 2007, 2008; Amaral and Quintin, 2010). Buera and Shin (2010) and Buera et al. (2011) show the importance of endogenous saving responses and general equilibrium effects through interest rates in quantitative assessment.

This paper is the first to quantitatively evaluate the (short-run and long-run) aggregate impact of microfinance as a targeted form of financial intermediation. We follow the above literature by evaluating microfinance within a model that incorporates occupational choice, 
endogenous wages and interest rates, and forward-looking saving decisions. ${ }^{7}$

Microfinance or microcredit has been viewed as a technological or policy innovation enhancing the repayment probability of uncollateralized loans. Alternative theories of the precise nature of this technology have been proposed, including joint liability lending (Besley and Coate, 1995), high-frequency repayment (Jain and Mansuri, 2003; Fischer and Ghatak, 2010), and dynamic incentives (Armendariz and Morduch, 2005). Unfortunately, empirical tests of the relative importance of these alternative mechanisms have not produced a clear answer as to what leads to high repayment rates (Ahlin and Townsend, 2007; Field and Pande, 2008; Gine and Karlan, 2010; Carpena et al., 2010; Attanasio et al., 2011). In this paper, we take an agnostic approach to the nature of this technology and simply model it as an innovation that enables the extension and full repayment of uncollateralized loans of certain sizes.

There is a growing empirical literature evaluating microfinance. The closest related study is Kaboski and Townsend (2012), who study a large-scale intervention that injected funds into Thai villages. The intervention led to positive impacts on village-level wages, which is interpreted as localized general equilibrium effects. Kaboski and Townsend find increases in income and business income but not actual business starts. Their companion paper (Kaboski and Townsend, 2011) finds increases in investment, but it is stressed that microfinance availability induces investment only for those close to the investment margin. As a result, the authors caution that large samples are required to pick up the impacts on investment. ${ }^{8}$ The most pronounced impact of the program was on consumption, however. Kaboski and Townsend (2011) note that the the impacts on consumption are heterogeneous, varying across investors vs. non-investors and also across borrowers vs. non-borrowers.

The rest of this literature has focused on estimating short-run partial equilibrium impacts of relatively small interventions. Each study and intervention is in some sense unique, but, with one exception, they generally find positive impacts on business activity. Some also find impacts on aggregate consumption and expenditures as well, but most studies emphasize the heterogeneous impacts across the population and the impacts on the composition of consumption (e.g., consumer durables).

\footnotetext{
${ }^{7}$ Ahlin and Jiang (2008) study the aggregate impact of microfinance within the context of Banerjee and Newman (1993). The analysis is theoretical rather than quantitative. They show that, in a model with exogenous saving decisions and interest rates, general equilibrium effects through wages can affect the ability to finance large-scale projects, which in turn determines whether microfinance increases or decreases aggregate output in the steady state.

${ }^{8}$ In a recent study examining the same intervention but using a larger, more representative sample, Buehren and Richter (2010) find significant positive impacts on workers entering into entrepreneurship. However, the study lacks a baseline and the entrepreneurship result does not use an instrument to account for potential endogeneity.
} 
The earliest study by Pitt and Khandker (1998) found positive impacts on expenditures and hours worked, especially among women for whom most work is self-employment. Banerjee et al. (2009), analyzing another randomized intervention with a much larger sample, find positive impacts on business starts rather than just on labor supply, business income/profits, or investment. ${ }^{9}$ Two other studies have examined randomized interventions granting microcredit to existing business owners (Karlan and Zinman, 2010) or livestock farmers (Crépon et al., 2011). Crépon et al. find an expansion in output, income, expenses, and labor, but they have few results for business owners, who represent only a small fraction of their sample. Karlan and Zinman, studying relatively small loans, find no significant impact on investment, and actually find reductions in the number of businesses and labor hired, which they interpret as a response to improved risk-coping. Banerjee et al., Crépon et al., and Karlan and Zinman all fail to find a significant impact on aggregate consumption and expenditures, but Banerjee et al. do confirm heterogeneous impacts on consumption, even among those who do not own business, driven presumably by changes in saving behavior rather than general equilibrium effects. Finally, Attanasio et al. (2011) find substantial increases in entrepreneurship but only among females and the less educated, and only when microfinance loans are joint liability. They consider joint liability as a way of better monitoring the use of funds.

In summary, both the mechanisms and impacts of microfinance appear to be quite nuanced. A substantial amount of evidence is in line with the microfinance narrative that loans are used for business purposes, and prima facie in line with the aforementioned theories at least qualitatively. There is also evidence that microfinance loans are used for consumer credit or risk-coping, which cuts against the microfinance narrative. We perform a more critical comparison of these empirical findings with our model predictions in Section 3.3.

\subsection{Savings Heterogeneity}

A central feature of our mechanism is the differential endogenous saving rates between entrepreneurs and workers, and between high-ability and low-ability individuals. In this section we present empirical support for these patterns.

Quadrini (1999), Gentry and Hubbard (2000), and Buera (2009) provide evidence of saving behavior among entrepreneurs and non-entrepreneurs in the US that is consistent with the mechanism that we emphasize. Using data from two rounds of the Survey of Consumer Finance and defining savings as the change in net worth, Gentry and Hubbard find that the median saving rates for entrants and continuing entrepreneurs were 36 percent and 17 percent, respectively. In comparison, the median saving rate for non-entrepreneurs

\footnotetext{
${ }^{9}$ Kaboski and Townsend (2005) find evidence of increased occupational mobility, but the exogenous variation in microfinance availability in their sample was driven by training and saving related policies.
} 
was just 4 percent, and that for exiting entrepreneurs was minus 48 percent. The pattern is robust to regression analyses that include demographic controls. Quadrini analyzes data from the Panel Study of Income Dynamics and finds that the propensity for entrepreneurship is significantly related to higher rates of wealth accumulation, even after controlling for income. Buera confirms that business owners save on average 26 percent more than non-business owners, but also shows that, just prior to starting a business, future business owners save on average 7 percent more than non-business owners. It is also shown that, after entry, young entrepreneurs have higher saving rates than mature entrepreneurs.

In the context of a developing country, Pawasutipaisit and Townsend (2010) use monthly longitudinal surveys to construct corporate accounts for households in rural and semi-urban Thailand. They have several findings that are relevant to our study. First, an individual's returns on assets are highly persistent, and they are therefore interpreted as a measure of individual-specific productivity. Second, increases in net savings are positively associated with the return on assets (correlation of 0.53 ) and also the saving rate (correlation of 0.21), both of which are significant at the one-percent level. These significant positive relationships are robust to the addition of control variables and fixed effects, instrumenting for productivity, and using TFP estimates as an alternative measure of productivity.

Although the Thai economy is a very different environment from the US, all of the studies provide evidence that entrepreneurial ability matters for saving behavior. ${ }^{10}$

\section{Model}

In this section, we introduce the baseline model with which we evaluate the aggregate and distributional impacts of microfinance.

There are measure $N$ of infinitely-lived individuals, who are heterogeneous in their wealth and the quality of their entrepreneurial idea or ability, $z$. Individuals' wealth is determined endogenously by forward-looking saving behavior. The entrepreneurial idea is drawn from an invariant distribution with cumulative distribution function $\mu(z)$. Entrepreneurial ideas "die" with a constant hazard rate of $1-\gamma$, in which case a new idea is drawn from $\mu(z)$ independently of the previous idea; that is, $\gamma$ controls the persistence of the entrepreneurial idea or talent process. The death of ideas can be interpreted as changes in market conditions that affect the profitability of individual skills or business opportunities.

In each period, individuals choose their occupation: whether to work for a wage or operate

\footnotetext{
${ }^{10}$ As for entry decisions, in the US, entrepreneurial decisions are a reasonable proxy for entrepreneurial ability because financial markets are relatively developed: Entry depends less on wealth and more on ability (Hurst and Lusardi, 2004). However, in Thailand, where financial frictions are stronger, entrepreneurial decisions are more constrained by wealth and thus less related to ability (Paulson and Townsend, 2004).
} 
a business (entrepreneurship). Their occupation choices are based on their comparative advantage as an entrepreneur $(z)$ and their access to capital. Access to capital is limited by their wealth through an endogenous collateral constraint, because of imperfect enforceability of capital rental contracts. We model microfinance as an innovation that guarantees the access to and repayment of a uncollateralized loan of certain sizes regardless of entrepreneurs' wealth or ability.

One entrepreneur can operate only one production unit (establishment) in a given period. Entrepreneurial ideas are inalienable, and there is no market for managers or entrepreneurial talent.

\subsection{Preference}

Individual preferences are described by the following expected utility function over sequences of consumption $c_{t}$ :

$$
U(c)=\mathbb{E}\left[\sum_{t=0}^{\infty} \beta^{t} u\left(c_{t}\right)\right], \quad u\left(c_{t}\right)=\frac{c_{t}^{1-\sigma}}{1-\sigma},
$$

where $\beta$ is the discount factor, and $\sigma$ is the coefficient of relative risk aversion. The expectation is over the realizations of entrepreneurial ideas $(z)$, which depend on the stochastic death of ideas $(1-\gamma)$ and the draws from $\mu(z)$.

\subsection{Technology}

At the beginning of each period, an individual with entrepreneurial idea or ability $z$ and wealth $a$ chooses whether to work for wage or operate a business. An entrepreneur with productivity $z$ produces using capital $(k)$ and labor $(l)$ according to:

$$
z f(k, l)=z k^{\alpha} l^{\theta}
$$

where $\alpha$ and $\theta$ are the elasticities of output with respect to capital and labor, and $\alpha+\theta<1$, implying diminishing returns to scale in variable factors at the establishment level.

With factor prices $w$ (wage) and $R$ (rental rate of capital), the profit of an entrepreneur is:

$$
\pi(k, l)=z k^{\alpha} l^{\theta}-R k-w l .
$$

For later use, we define the optimal level of capital and labor inputs when production is not subject to financial constraints:

$$
\left(k^{u}(z), l^{u}(z)\right)=\arg \max _{k, l}\left\{z k^{\alpha} l^{\theta}-R k-w l\right\} .
$$




\subsection{Credit (Capital Rental) Markets}

We first describe credit markets in the absence of microfinance. Individuals have access to competitive financial intermediaries, who receive deposits and rent out capital $k$ at rate $R$ to entrepreneurs. We restrict the analysis to the case where credit transactions are within a period - that is, individuals' financial wealth is restricted to be non-negative $(a \geq 0)$. The zero-profit condition of the intermediaries implies $R=r+\delta$, where $r$ is the deposit rate and $\delta$ is the depreciation rate.

Capital rental by entrepreneurs is limited by imperfect enforceability of contracts. In particular, we assume that, after production has taken place, entrepreneurs may renege on the contracts. In such cases, entrepreneurs can keep a fraction $1-\phi$ of the undepreciated capital and the revenue net of labor payments: $(1-\phi)[z f(k, l)-w l+(1-\delta) k], 0 \leq \phi \leq 1$. The only punishment is the garnishment of their financial assets deposited with the financial intermediary, $a$. In the following period, the entrepreneurs in default regain access to financial markets and are not treated any differently, despite their history of default.

This one-dimensional parameter $\phi$ captures the extent of frictions in the financial market owing to imperfect enforcement of credit contracts. We view it as reflecting the strength of an economy's legal institutions in enforcing contractual obligations. This parsimonious specification allows for a flexible modeling of limited commitment that spans economies with perfect credit markets $(\phi=1)$ and no credit or 100-percent self-financing $(\phi=0)$.

We consider equilibria where the borrowing and capital rental contracts are incentivecompatible and are hence fulfilled. In particular, we study equilibria where the rental of capital is quantity-restricted by an upper bound $\bar{k}(a, z ; \phi)$, which is a function of the individual state $(a, z)$. We choose the rental limits $\bar{k}(a, z ; \phi)$ to be the largest limits that are consistent with entrepreneurs choosing to abide by their credit contracts. Without loss of generality, we assume $\bar{k}(a, z ; \phi) \leq k^{u}(z)$, where $k^{u}$ is the profit-maximizing capital inputs in the unconstrained static problem.

The following proposition, proved in Buera et al. (2011), provides a simple characterization of the set of enforceable contracts and the rental limit $\bar{k}(a, z ; \phi)$.

Proposition 1 Capital rental $k$ by an entrepreneur with wealth a and talent $z$ is enforceable if and only if

$$
\max _{l}\{z f(k, l)-w l\}-R k+(1+r) a \geq(1-\phi)\left[\max _{l}\{z f(k, l)-w l\}+(1-\delta) k\right] .
$$

The upper bound on capital rental that is consistent with entrepreneurs choosing to abide by the contracts can be represented by a function $\bar{k}(a, z ; \phi)$, which is increasing in $a, z$, and $\phi$. 
Condition (2) states that an entrepreneur must end up with (weakly) more economic resources when he fulfills his credit obligations (left-hand side) than when he defaults (righthand side). This static condition is sufficient to characterize enforceable allocations because we assume that defaulting entrepreneurs regain full access to financial markets in the following period.

This proposition also provides a convenient way to operationalize the enforceability constraint into a simple rental limit $\bar{k}(a, z ; \phi)$. Rental limits increase with the wealth of entrepreneurs, because the punishment for defaulting (loss of collateral) is larger. Similarly, rental limits increase with the talent of an entrepreneur because defaulting entrepreneurs keep only a fraction $1-\phi$ of the output.

\subsection{Microfinance}

We model microfinance as an innovation in financial technology that guarantees individuals' access to and repayment of capital input of certain sizes. To be more specific, we incorporate microfinance by relaxing individuals' capital rental limit into the following constraint:

$$
k \leq \max \left\{\bar{k}(a, z ; \phi), a+b^{M F}\right\}
$$

where $b^{M F}$ denotes the intra-period credit limit of (i.e., the additional capital provided by) the microfinance innovation. Note that an entrepreneur chooses either to rent from the financial intermediary subject to the endogenous rental limit $\bar{k}(a, z ; \phi)$ or to use microfinancing to top up his self-financed capital $a+b^{M F}$. Because $\bar{k}$ is increasing in $a$ and $z$ while $b^{M F}$ is a constant, microfinance will be primarily used by poor and/or low-ability entrepreneurs. For rich and high-ability entrepreneurs, their opportunity set is unaffected by microfinance. We will more explicitly analyze the take-up of microfinance in Section 3.3.

Our modeling of microfinance can be interpreted as a technological innovation that enables financial intermediaries to receive full repayment on small uncollateralized loans. ${ }^{11}$ Alternatively, microfinance can be thought of as a government policy that guarantees loans for small firms, such as that of the US Small Business Administration. Either way, we are abstracting from the cost of operating microfinance institutions or the cost of default and implicit subsidy to defaulters. In this context, our results should be interpreted as an upper bound on the possible gains from microfinance.

\footnotetext{
${ }^{11}$ As discussed in Section 1.2, the exact nature of this innovation is a subject of debate and is thought to take the form of dynamic incentives, joint liability, and/or community sanctions.
} 


\subsection{Recursive Representation of Individuals' Problem}

Individuals maximize (1) by choosing sequences of consumption, financial wealth, occupation, and entrepreneurial capital/labor inputs, subject to a sequence of period budget constraints and rental limits.

At the beginning of a period, an individual's state is summarized by his wealth $a$ and ability $z$. He then chooses whether to be a worker or to be an entrepreneur for the period. The value for him at this stage, $v(a, z)$, is the larger of the value of being a worker, $v^{W}(a, z)$, and the value of being an entrepreneur, $v^{E}(a, z)$ :

$$
v(a, z)=\max \left\{v^{W}(a, z), v^{E}(a, z)\right\} .
$$

Note that the value of being a worker, $v^{W}(a, z)$, depends on his entrepreneurial ability $z$, which may be implemented at a later date. We denote the optimal occupation choice by $o(a, z) \in\{W, E\}$.

As a worker, an individual chooses consumption $c$ and the next period's assets $a^{\prime}$ to maximize his continuation value subject to the period budget constraint:

$$
\begin{aligned}
& v^{W}(a, z)=\max _{c, a^{\prime} \geq 0} u(c)+\beta\left\{\gamma v\left(a^{\prime}, z\right)+(1-\gamma) \mathbb{E}_{z^{\prime}}\left[v\left(a^{\prime}, z^{\prime}\right)\right]\right\} \\
& \text { s.t. } c+a^{\prime} \leq w+(1+r) a,
\end{aligned}
$$

where $w$ is his labor income. The continuation value is a function of the end-of-period state $\left(a^{\prime}, z^{\prime}\right)$, where $z^{\prime}=z$ with probability $\gamma$ and $z^{\prime} \sim \mu\left(z^{\prime}\right)$ with probability $1-\gamma$. The expectation operator $\mathbb{E}_{z^{\prime}}$ stands for the integration with respect to $\mu\left(z^{\prime}\right)$. In the next period, he will face an occupational choice again, and the function $v(a, z)$ appears in the continuation value.

Alternatively, individuals can choose to become an entrepreneur. The value function of being an entrepreneur is as follows.

$$
\begin{aligned}
& v^{E}(a, z)=\max _{c, a^{\prime}, k, l \geq 0} u(c)+\beta\left\{\gamma v\left(a^{\prime}, z\right)+(1-\gamma) \mathbb{E}_{z^{\prime}}\left[v\left(a^{\prime}, z^{\prime}\right)\right]\right\} \\
& \text { s.t. } c+a^{\prime} \leq z f(k, l)-R k-w l+(1+r) a \\
& \quad k \leq \max \left\{\bar{k}(a, z ; \phi), a+b^{M F}\right\}
\end{aligned}
$$

Note that an entrepreneur's income is given by period profits $z f(k, l)-R k-w l$ plus the return to his initial wealth, and that his capital inputs are constrained by the larger of $\bar{k}(a, z ; \phi)$ and $a+b^{M F}$.

\subsection{Stationary Competitive Equilibrium}

A stationary competitive equilibrium is composed of: an invariant distribution of wealth and entrepreneurial ability with joint cumulative distribution function $G(a, z)$ and the marginal 
cumulative distribution function of $z$ denoted by $\mu(z)$; individual decision rules on consumption, asset accumulation, occupation, labor input, and capital input, $c(a, z), a^{\prime}(a, z), o(a, z)$, $l(a, z), k(a, z)$; rental limits $\bar{k}(a, z ; \phi)$; and prices $w, R, r$ such that:

1. Given $b^{M F}, \bar{k}(a, z ; \phi), w, R$, and $r$, the individual policy functions $c(a, z), a^{\prime}(a, z)$, $o(a, z), l(a, z), k(a, z)$ solve (4), (5) and (6);

2. Financial intermediaries make zero profit: $R=r+\delta$;

3. Rental limits $\bar{k}(a, z ; \phi)$ are the most generous limits satisfying condition (2), with $\bar{k}(a, z ; \phi) \leq k^{u}(z)$

4. Capital rental, labor, and goods markets clear:

$$
\begin{aligned}
& \frac{K}{N} \equiv \int k(a, z) G(d a, d z)=\int a G(d a, d z) \\
& \int l(a, z) G(d a, d z)=\int_{\{o(a, z)=W\}} G(d a, d z) \\
& \int c(a, z) G(d a, d z)+\delta \frac{K}{N}=\int_{\{o(a, z)=E\}}\left[z k(a, z)^{\alpha} l(a, z)^{\theta}\right] G(d a, d z)
\end{aligned}
$$

5. The joint distribution of wealth and entrepreneurial ability is a fixed point of the equilibrium mapping:

$$
G(a, z)=\gamma \int_{\left\{(\tilde{a}, \tilde{z}) \mid \tilde{z} \leq z, a^{\prime}(\tilde{a}, \tilde{z}) \leq a\right\}} G(d \tilde{a}, d \tilde{z})+(1-\gamma) \mu(z) \int_{\left\{(\tilde{a}, \tilde{z}) \mid a^{\prime}(\tilde{a}, \tilde{z}) \leq a\right\}} G(d \tilde{a}, d \tilde{z}) .
$$

In our analysis of the short-run effects of microfinance and also the welfare effects, we correctly account for the transitional dynamics to the new stationary equilibria. For this purpose, we can define competitive equilibrium in an analogous fashion as consisting of sequences of the joint wealth-ability distribution $\left\{G_{t}(a, z)\right\}_{t=0}^{\infty}$, policy functions, rental limits, and prices.

\section{Quantitative Analysis}

To quantify the aggregate and distributional impact of microfinance, we calibrate our model in two stages. First, using the US data on standard macroeconomic aggregates, we calibrate a set of technological and preference parameters that are assumed to be the same across countries. In the second stage, using data from India, we re-calibrate the parameter governing the enforceability of contracts and the one for the entrepreneurial ability distribution. 
We then conduct experiments to assess the effect of microfinance by varying $b^{M F}$, the credit limit. We first document the short-run impact of microfinance with fixed prices (i.e., partial equilibrium). The model implications are then compared with empirical evaluations of microfinance, which by design capture short-run PE effects. We show that the model matches key qualitative features found in microevaluations of microfinance initiatives, and that the quantitative magnitudes in the model are in line with the empirical estimates.

\subsection{Calibration}

We first calibrate preference and technology parameters so that the perfect-credit $(\phi=1)$ stationary equilibrium of the model economy matches key aspects of the US, a relatively undistorted economy. Our target moments pertain to standard macroeconomic aggregates and establishment size distribution, among others.

With $\phi=1$ given, we need to specify values for 7 parameters: 2 technological parameters, $\alpha$ and $\theta$; the depreciation rate $\delta ; 2$ parameters describing the process for entrepreneurial talent, $\gamma$ and $\eta$, where $\mu(z)=1-z^{-\eta}$; the subjective discount factor $\beta$; and the coefficient of relative risk aversion $\sigma$. Of these 7 parameters, $\eta$ will be re-calibrated below to match Indian data, together with $\phi$.

Of these, we set $\sigma, \alpha /(1 / \eta+\alpha+\theta)$, and $\delta$ to standard values in the literature. We let $\sigma=1.5$, the one-year depreciation rate be $\delta=0.06$, and $\alpha /(1 / \eta+\alpha+\theta)$ match the aggregate capital income share of $0.30 .^{12}$

\begin{tabular}{lccc}
\hline Target Moments & US Data & Model & Parameter \\
\hline Top 10-percentile employment share & 0.69 & 0.69 & $\eta=4.84$ \\
Top 5-percentile earnings share & 0.30 & 0.30 & $\alpha+\theta=0.79$ \\
Establishment exit rate & 0.10 & 0.10 & $\gamma=0.89$ \\
Interest rate & 0.04 & 0.04 & $\beta=0.92$ \\
\hline Target Moments & Indian Data & Model & Parameter \\
\hline Top 10-percentile employment share & 0.58 & 0.58 & $\eta=5.56$ \\
External finance to GDP ratio & 0.34 & 0.34 & $\phi=0.08$ \\
\hline
\end{tabular}

Table 2: Calibration

We are thus left with 4 parameters that are more specific to our study. We calibrate them to match 4 relevant moments in the US data shown in Table 2: the employment share of the top decile of establishments; the share of earnings generated by the top 5 percent of

\footnotetext{
${ }^{12}$ We are being conservative in choosing a relatively low capital share. The larger the share of capital, the bigger the role of capital misallocation and hence the effect of microfinance. We are also accommodating the fact that some of the payments to capital in the data are actually payments to entrepreneurial input.
} 
earners; the annual exit rate of establishments; and the annual real interest rate. Given the returns to scale, $\alpha+\theta$, we choose the tail parameter of the entrepreneurial talent distribution, $\eta=4.84$, to match the employment share of the largest 10 percent of establishments, 0.69 . We can then infer $\alpha+\theta=0.79$ from the earnings share of the top 5 percent of earners. Top earners are mostly entrepreneurs (both in the US data and in the model), and $\alpha+\theta$ controls the fraction of output going to the entrepreneurial input. The parameter $\gamma=0.89$ leads to an annual establishment exit rate of 10 percent in the model, which is the exit rate of establishments reported in the US Census Business Dynamics Statistics. ${ }^{13}$ Finally, the model requires a discount factor of $\beta=0.92$ to match the annual interest rate of 4 percent

We use the above parameter values calibrated to the US data for our analysis of microfinance, with two important exceptions. First, microfinance is implemented in countries with underdeveloped financial markets. Second, the establishment size distribution in less developed countries is vastly different from that of the US. Using detailed data available for India, we re-calibrate $\phi$ and $\eta$. The ratio of external finance to GDP in India is 0.34, which happens to be equal to the average ratio across non-OECD countries over the 1990s in the data assembled by Beck et al. (2000). This period is chosen because it immediately precedes the explosive proliferation of large-scale microfinance programs. Also, from the 1997 Indian Economic Census, we compute the employment share of the largest 10-percent of establishments to be 0.58 . A joint calibration leads to $\phi=0.082$ and $\eta=5.56$.

\subsection{Short-Run Partial Equilibrium Results}

We quantify the effects of microfinance for a wide range of $b^{M F}$. We begin by discussing the results of the short-run partial equilibrium analysis. This not only clarifies the mechanisms at work, but also facilitates our next step: a comparison of the model implications with several empirical evaluations of microfinance initiatives.

We begin in the stationary equilibrium (as defined in Section 2.6) without microfinance, $b^{M F}=0$. The short-run PE impacts we now discuss refer to the outcome one period after the introduction of the microfinance (i.e., short run), where the wage and interest rate are kept constant (i.e., partial equilibrium) at their levels in the initial $b^{M F}=0$ equilibrium. As such, market clearing conditions are ignored.

In the left panel of Figure 1, we show aggregate output, capital, and the total labor input, which includes both entrepreneurs and employed workers, for various levels of $b^{M F}$. Aggregate output here follows the GDP concept, inclusive of the contributions of the production factors from outside the economy. With positive $b^{M F}$, the economy uses more workers and

\footnotetext{
${ }^{13}$ Note that $1-\gamma$ is larger than 0.1 , because a fraction of those hit by the idea shock chooses to remain in business. Entrepreneurs exit only if their new idea is below the equilibrium cutoff level.
} 

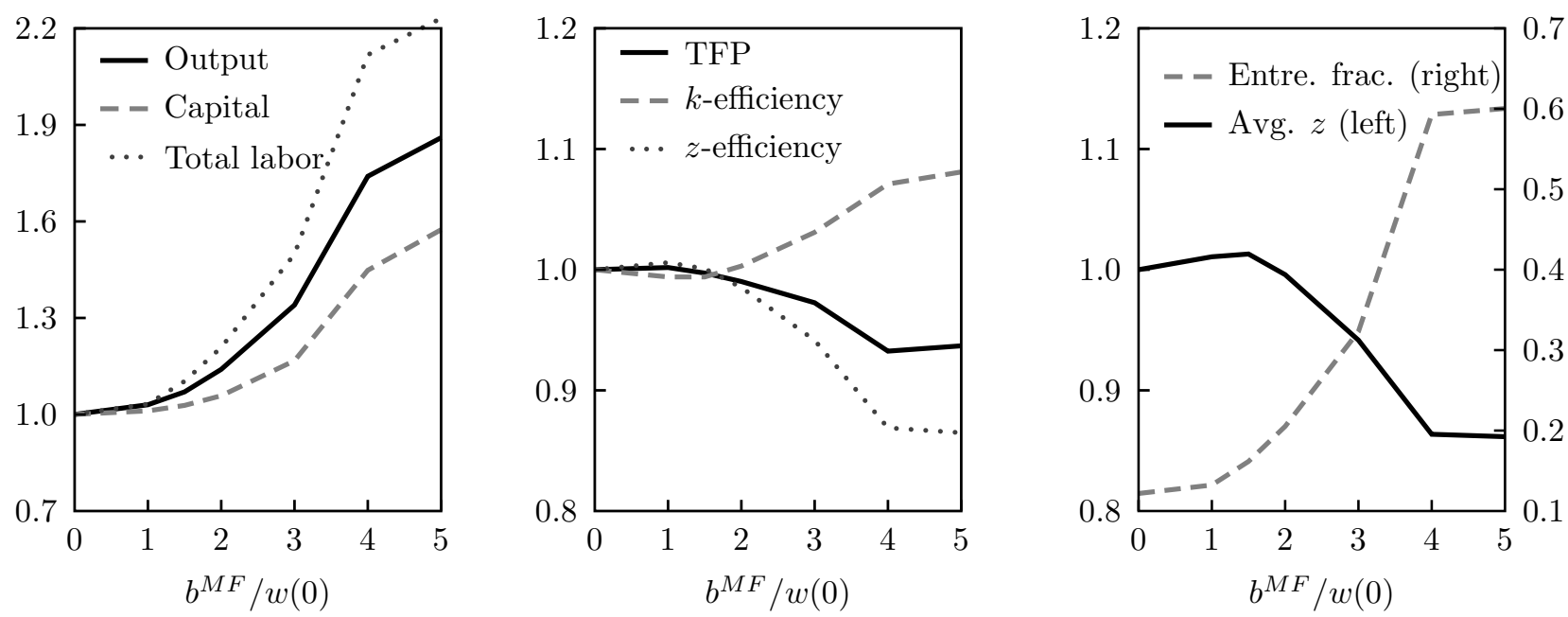

Fig. 1: Short-Run Aggregate Implications in Partial Equilibrium

capital than it has. (No outside entrepreneur is allowed in, though.) Indeed, the total labor and capital in excess of 1 in the figure are the workers and capital inputs from outside the economy. On the horizontal axis, $b^{M F}$ relative to the equilibrium wage in the $b^{M F}=0$ economy (i.e., $b^{M F}$ divided by $w\left(b^{M F}=0\right)$ ) is shown, ranging from 0 to 5 . All three aggregate quantities are normalized by their respective levels in the $b^{M F}=0$ equilibrium. The pattern is clear: All three quantities increase monotonically, with output increasing by 85 percent, total labor input by 120 percent, and capital by 65 percent, as $b^{M F}$ goes from 0 to 5 times the initial equilibrium wage. The income of the original population, net of factor payments to the "excess" workers and capital, increases much more modestly: It rises by 15 percent, as $b^{M F}$ goes from 0 to 5 times the normalizing wage (not shown in the figure), and most of this increase materializes through the income of marginal entrepreneurs who switch from being a worker because of microfinance.

Nevertheless, the overall efficiency of production declines, as is attested by the 6-percent drop in TFP shown by the solid line in the center panel of Figure 1. In theory, microfinance affects the aggregate productivity through the intensive margin of capital allocation - as it relaxes credit constraints - and the extensive margin, i.e., the entry into and exit from entrepreneurship. Microfinance generally has a positive impact on the allocative efficiency of capital along the intensive margin: For a fixed set of entrepreneurs, it either relaxes or leaves alone entrepreneurial credit constraints. In the right panel of Figure 1, we show how dramatic its impact on the extensive margin is. The dashed line, which should be read off the right vertical axis, plots the number of active entrepreneurs relative to the economy's population size. Over the range of $b^{M F}$ we consider, it increases by a factor of 5 (from 0.12 to 0.6). We emphasize that, as shown in equation (3), microfinance most directly affects poor 
and/or marginal-ability individuals. ${ }^{14}$ With more generously-sized microcredit, individuals with merely marginal entrepreneurial ability suddenly find it profitable to enter into business: As the number of entrepreneurs increase, the average ability $(z)$ among active entrepreneurs decline (solid line, right panel), which is normalized by its level in the no-microfinance equilibrium. This explains the fall in the aggregate productivity. Note, however, that the average ability as a function of $b^{M F}$ is nonmonotonic. For small enough $b^{M F}$, microfinance induces the entry of only those who are highly able but poor: The credit is too small to alter the occupation choice of less productive individuals, who remain as workers. This is why the average ability of active entrepreneurs actually increases with $b^{M F}$ up to 1.5 times the normalizing wage.

In the center panel of Figure 1, we decompose the effect of microfinance on aggregate TFP into changes in the allocation of production resources at the intensive margin and the extensive margin. The solid line is the aggregate TFP in the short-run partial equilibrium following the implementation of microfinance with various $b^{M F}$. The dashed line, $k$-efficiency, represents the effect of better capital allocation among existing entrepreneurs (intensive margin), while the dotted line, $z$-efficiency, shows the effect through selection into entrepreneurship (extensive margin). The product of these two lines is equal to the solid line. The formulas for this decomposition are derived and explained in the appendix. If there were no effect, the two lines would have been flat at 1 . For either margin, being above 1 implies that microfinance improves the aggregate productivity through that margin, and, likewise, being below 1 means that microfinance hurts the aggregate productivity through that margin. As discussed above, through the massive entry of marginal entrepreneurs (extensive margin), microfinance actually has a significant negative impact on aggregate TFP, as shown by the dotted line. While microfinance does improve capital allocation at the intensive margin, as shown by the dashed line, this effect is dominated by the negative effect through the extensive margin.

In summary, in the short-run partial equilibrium, microfinance has a large positive impact on business starts, capital inputs, and labor inputs, leading to a significant increase in aggregate output. The overall efficiency of production suffers, however, as microfinance eventually leads to the entry of less productive entrepreneurs. We will see in Section 4 that these conclusions are drastically altered in the general equilibrium.

\footnotetext{
${ }^{14}$ To give an idea, those who choose to be entrepreneurs both with and without microfinance increase their hiring by only 9 percent as $b^{M F}$ goes from 0 to 5 , which is dwarfed by the 120 -percent increase in total labor input (dotted line, left panel).
} 


\subsection{Comparison with Microevaluations}

We now compare the above short-run PE predictions of our model with two recent microevaluations: the urban Indian Spandana study by Banerjee et al. (2009) and the rural Thai Million Baht Village Fund program evaluation by Kaboski and Townsend (2011, 2012). The scale of these programs are small relative to the macroeconomy of either country, and hence a PE analysis is appropriate. ${ }^{15}$ In addition, the microevaluations were conducted within a year or two of the launching of the programs, and hence we compare them with the shortrun predictions of the model. These two empirical studies are chosen because they closely examine the patterns most relevant to our model: entrepreneurship, investment, and consumption/saving. Nevertheless, we discuss relevant results from other studies later in this section.

While our model economy does not map perfectly into the environment and the programs analyzed in these papers, which are very different from each other in important ways to begin with, we gauge whether the mechanisms in our model speak to the results in the empirical work. In other words, we use these microevaluations as out-of-sample evidence on the validity of the model, before making short-run and long-run GE predictions.

We compare along three dimensions: the amount of microfinance borrowing, the impact on investment activities (entrepreneurship and investment), and the impact on consumption. We find that the model performs reasonably well on each front, although the model overpredicts impacts on investment and underpredicts impacts on consumption. This is as expected, because we do not model consumption loans which are an important use of microcredit in both empirical studies: The microfinance intervention in our model directs all credit toward entrepreneurial activities but none toward consumption.

The Indian study involved a randomized expansion of MFI branches across different neighborhoods in Hyderabad. The follow-up survey was conducted about 18 months after loans had been disbursed. Loan amounts ranged from 10,000 to 20,000 rupees, or roughly 1 to 2 times the annual per-capita expenditures in the baseline survey (12,000 rupees). ${ }^{16}$ The randomization led to an increase of roughly 1,300 rupees of microcredit per capita, or just over 0.1 when normalized by annual expenditures. It was a 50-percent increase over the baseline level of microcredit per capita (2,400 rupees). The post-intervention level

\footnotetext{
${ }^{15}$ As we discuss below, the Thai program was sizable in that it affected all villages across the country and amounted to 1.5 percent of GDP. Still, 1.5 percent of GDP is an order of magnitude smaller than the amounts in our GE analysis, so we view the PE analysis as providing a reasonable comparison with the Thai studies. Nevertheless, for the smallest villages, the intervention was relatively large, amounting to 40 percent of average annual income, and significant GE effects were detected at the village level (Kaboski and Townsend, 2012).

${ }^{16}$ The per-capita numbers in the empirical studies are actually per adult equivalent.
} 
of total microcredit constituted about 42 percent of total credit in the survey area. The loans also had a positive effect on entrepreneurship: Households in the treatment group are 1.7 percentage points more likely to open a new business from a baseline of 5.4 percent. The impacts on the revenues, assets, and profits of existing business owners are positive but all statistically insignificant. However, the loans did produce a significant increase in durable goods consumption of 16 percent, and a significant increase in durable goods used for businesses of 128 percent.

The Thai study involved a government transfer of 1 million baht of seed money to each selected rural village for the purpose of founding village lending funds. ${ }^{17}$ Since villages differ in their size, 1 million baht was tantamount to more than 25 percent of total annual income in the smallest village but less than 0.2 percent in the largest village, which is an important source of exogenous variation. This intervention indeed led to general equilibrium impacts in the form of higher wages in some small villages. Loan sizes were about 20,000 baht, roughly equal to the annual expenditures per capita $(22,000$ baht) in the survey area. Since impacts are measured as coefficients on continuous variables, we report impacts for the median village. The loans from the injected funds were 2,300 baht per capita- or again roughly 0.1 as a fraction of annual per-capita expenditures - and constituted one-third of total credit in the median village. The point estimate of a 15-percent increase in new businesses (or a 1-percentage-point increase in the rate of entrepreneurial entry) is statistically insignificant, but the credit did lead to a 56-percent increase in business profits. ${ }^{18}$ The injected credit had no measurable impact on the aggregate investment, but it significantly increased the probability of making discrete investments by 35 percent - from 0.11 to $0.15 .{ }^{19}$ The credit led to a significant increase in per-capita consumption of 15 percent, with essentially no impact on durable goods consumption, and also an 11-percent increase in income by the end of the second year.

For the model, we choose $b^{M F}=1.5 w(0)$, which yields a maximum loan size relative to consumption of 1, comparable to these real-world programs. Our short-run (i.e., oneyear) results match up well with the horizon of the empirical studies. Table 3 summarizes the aggregate impact from the two studies and the model. The resulting microcredit per

\footnotetext{
${ }^{17}$ The results here are taken from Kaboski and Townsend (2012), with the exception of new business starts and business profits, which are from Kaboski and Townsend (2011).

${ }^{18}$ Buehren and Richter (2010) find a significant increase in the flow of workers to entrepreneurs. Their point estimate implies a 5 percentage point increase in entrepreneurship. They use a larger, nationally representative sample, but they do not have a baseline and do not use an instrument to address potential endogeneity.

${ }^{19}$ The point estimate of the effect on aggregate investment is actually minus 4 percent, but the standard error is 4 times the coefficient. Kaboski and Townsend (2012) emphasize that much larger samples are needed to estimate impacts on levels of investment given the infrequent, lumpy investments.
} 


\begin{tabular}{lccc}
\hline & Model & India & Thailand \\
\hline Max loan size to per-capita expenditures & 1 & $1-2$ & 1 \\
Microcredit relative to expenditures & 0.1 & 0.1 & 0.1 \\
Microcredit relative to total credit & 0.29 & 0.42 & 0.33 \\
Entrepreneurship & +4 p.p. & +2 p.p. & +1 p.p. \\
Investment & $+46 \%$ & $+16-128 \%$ & $+35 \%$ (Prob.) \\
Consumption & $+1 \%$ & $+16 \%$ (Durables) & $+15 \%$ \\
\hline
\end{tabular}

Table 3: Comparison Summary

capita relative to per-capita consumption is 0.1 in the model, just like in the two studies. Microcredit as a whole constitutes a smaller fraction of total credit, 29 percent, in the model than in the data. However, we note that the total credit in the model also includes the external financing of very large firms. Such formal, large-scale external finance does exist in India and Thailand, but was not part of the studies' surveys of local neighborhoods and villages.

The impact on entrepreneurship is larger in the model than in the empirical studies, increasing the fraction of entrepreneurs in the population by 4 percentage points. ${ }^{20} \mathrm{We}$ also find large increases in investment of 46 percent. On the other hand, we find a small1 percent-increase in consumption, substantially less than the (statistically insignificant) point estimate of 16 percent in India and the significant 15-percent increase in Thailand. Again, the model overpredicts impacts on entrepreneurship/investment and underpredicts impacts on consumption, primarily because we do not model pure consumption loans. All microcredit in the model is business loans, but pure consumption loans are also an important part of the real-world microfinance programs. In addition, at least for the Thai study, higher wages resulting from the credit program in some villages may be driving the consumption increase and partly suppressing the entry into entrepreneurship. ${ }^{21}$

Both Banerjee et al. and Kaboski and Townsend emphasize that the impacts are heterogeneous. They find that marginal entrepreneurs/investors are more likely to increase investment and decrease consumption, while others are more likely to simply increase consumption. ${ }^{22}$ Microfinance in our model, even in partial equilibrium, also affects individuals in a heterogenous fashion, most directly benefitting poor, marginal entrepreneurs. In addition, our model is consistent with the increase in investment and the corresponding decline

\footnotetext{
${ }^{20}$ In percentage terms, the increase in the number of entrepreneurs is even larger in the model, since entrepreneurship rates are substantially higher in the Indian and Thai surveys.

${ }^{21}$ We also computed a short-run GE version of our model with $b^{M F}=1.5 w(0)$. The magnitude of the wage increase in this exercise, 4.5 percent, is somewhat smaller than the 7-percent wage increase estimated by Kaboski and Townsend (2012) for the similarly-sized Thai intervention.

${ }^{22}$ While Banerjee et al. look at marginal entrepreneurs in the data, Kaboski and Townsend have individuals on the margin of making discrete investments.
} 
in consumption among marginal entrepreneurs.
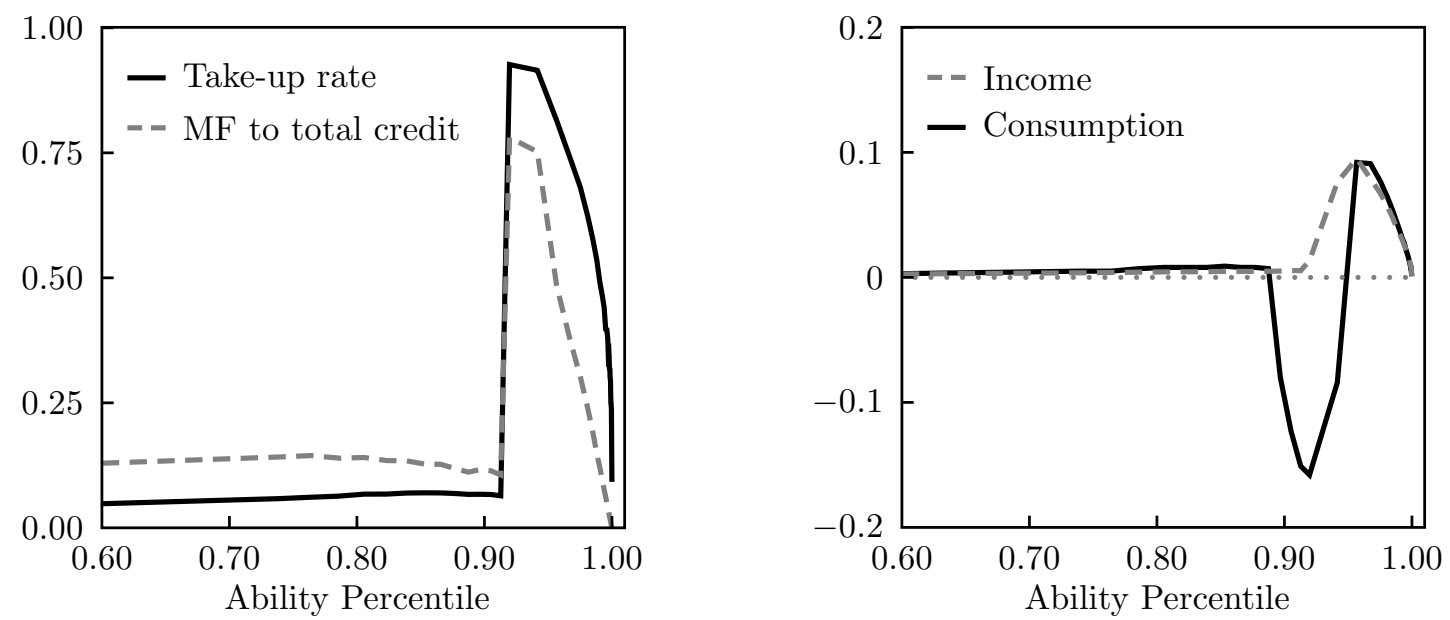

Fig. 2: Micro-Level Implications for $b^{M F}=1.5 w(0)$

The model's heterogeneous impacts on credit take-up and consumption are shown in Figure 2. In the left panel, we plot the take-up rate of microfinance loans (solid line) and microfinance as a fraction of total external finance (dashed line) for each entrepreneurial ability level (horizontal axis). We compute what fraction of the individuals with a given ability level actually take up on the microcredit offer (take-up rate), and also how the utilized microcredit measures up to the total external finance used by active entrepreneurs of that ability. We emphasize that take-up rate is low overall, integrating out to 11 percent for the entire population, although it can be as high as 90 percent for those with marginal entrepreneurial ability. The low overall take-up rate is consistent with the findings in the Indian study, where treatment increased the fraction of households that take out microcredit by only 13 percentage points.

In the right panel, we show the heterogeneous impacts on income (dashed line) and consumption (solid line) in the model, for each ability level (horizontal axis). By construction, microfinance in the model induces marginal-ability individuals into entrepreneurship, who would have been workers without it, raising their income. Those with very low abilities remain workers even with microfinance, and hence their income is not affected. The same goes for the most talented and richest entrepreneurs, whose opportunity set is not affected by microfinance. More important, for the marginal entrepreneurs who switch occupations because of microfinance, their consumption actually decreases even though their income is now higher. This is because the new entrepreneurs have strong self-financing motive for saving, so that they can overcome collateral constraint and scale up their business to more profitable levels in future periods. In other words, their returns to saving are now much higher than before. This fall in consumption among marginal entrepreneurs is also observed 
in both the Indian and the Thai studies, which report a decline in the current consumption of investors or those likely to invest on average.

In addition, Banerjee et al. find that new entrants under microfinance are smaller, employing 0.2 fewer workers on average. Our model also predicts that new entrants have 0.1 fewer workers. Banerjee et al. also find that new entrepreneurs with microfinance are concentrated in small-scale, low fixed-cost industries. In Section 4.3.3, we replicate this pattern using a two-sector version of our model.

In the introduction and again in Section 1.2, we mentioned three other studies that examine the impact of microfinance on productive activities: Attanasio et al. (2011), Karlan and Zinman (2010), and Crépon et al. (2011). Each evaluates a more targeted program, but their results are nonetheless of interest. Attanasio et al. (2011) evaluate the expansion of a particular type of microfinance - i.e., joint liability loans targeted toward women - in rural Mongolia, a country where other forms of microfinance are already wide-spread (Table 1). The size and the (short-term) maturity of loans were similar to those of the Thai and Indian programs. Despite the existing prevalence of microloans, the authors find a large (10 percentage point) and significant increase in the probability of female-owned businesses. This impact is concentrated among the less educated, however, and is only observed for joint liability loans rather than individual loans (the more common loans in Mongolia). They also find a significant increases in food consumption (17 percent) and the probability of owning major appliances (9 percent). The increase in total consumption, however, is not statistically significant, nor is there a significant impact on total assets or income.

The other two studies are less relevant to understanding the impact on the extensive margin of borrowers starting businesses, since the interventions targeted only existing entrepreneurs. They still give insights into impacts on the intensive margins, however. Karlan and Zinman (2010) examine loans to existing business owners who are marginal borrowers in Manila. Loans were much smaller-less than one month's per-capita income - even for the median borrower. Nevertheless, the increased microfinance loans amounted to 24 percent of total credit for those borrowers. The point estimate on profits implies an increase of 5 percent, but this is insignificant. The number of businesses per household fell from 1.4 to 1.3, and the number of paid workers fell from 0.9 to 0.6. Crépon et al. (2011) evaluate the impact of expanding the lending activities of existing MFI branches to rural villages in Morocco. Here, the loans were large, with the maximum loan size amounting to 5 times the average expenditures per capita. The increase in microfinance credit amounted to 28 percent of baseline credit, and 31 percent of annual expenditures in the control. In this economy, households are quite poor and the vast majority of them operate their own technology, with 69 percent in livestock businesses and 14 percent in non-agricultural businesses. The im- 
pacts on business output, expenses, and employment were all statistically significant, with increases of 14, 13, and 53 percent respectively. Although the intervention is not particularly well-suited for studying the extensive margin, the authors find a marginally significant 4 percentage point increase in the fraction of households in livestock farming, offset by a significant 4 percentage point decrease in non-agricultural businesses. Our extension modeling an economy where a large segment of the population is forced into self-employment because of labor market frictions (Section 4.3.2) is perhaps more relevant to this agrarian economy.

In summary, the microevaluations give a nuanced picture of microfinance. Sometimes we see impacts on investment and entrepreneurship in line with the narrative of microfinance as capital for entrepreneurial production, but not always. Although our model abstracts from consumption loans, it captures many of the aggregate and heterogeneous impacts of microfinance on entrepreneurship, investment, and consumption/saving that are emphasized in various empirical evaluations of microfinance. This result gives credence to the validity of using our model to analyze the impacts of microfinance. We now use the model to evaluate the long-run impacts of microfinance in general equilibrium. For obvious reasons, there is no empirical studies evaluating such impacts.

\section{Microfinance in General Equilibrium}

We evaluate the long-run effects of microfinance, contrasting the GE vs. PE impacts. We then show the importance of GE considerations for the welfare implications of economy-

wide microfinance. Finally, we explore three additional modeling assumptions that may be important for understanding the impact of microfinance.

\subsection{Partial vs. General Equilibrium}

Before we discuss the long-run GE effects of microfinance, we first show in Figure 3 the long-run aggregate impact for various values of credit limit $b^{M F}$, holding prices fixed at their levels in the initial steady state without microfinance (i.e., partial equilibrium).

Relative to the short-run results in Figure 1, the long-run impacts on aggregate output and capital are significantly larger, respectively by about 25 percent and 33 percent. These differences are driven by the asset accumulation dynamics, which by construction is absent in the short-run analysis. The marginal entrepreneurs who are the most directly affected by microfinance now have higher income and also higher saving rates for self-financing reasons. Over time, they will accumulate more and more assets and overcome the collateral constraint. As a result, with more wealth and collateral in the economy, the aggregate capital used for production increases further. Asset accumulation over time also induces even more entry of 


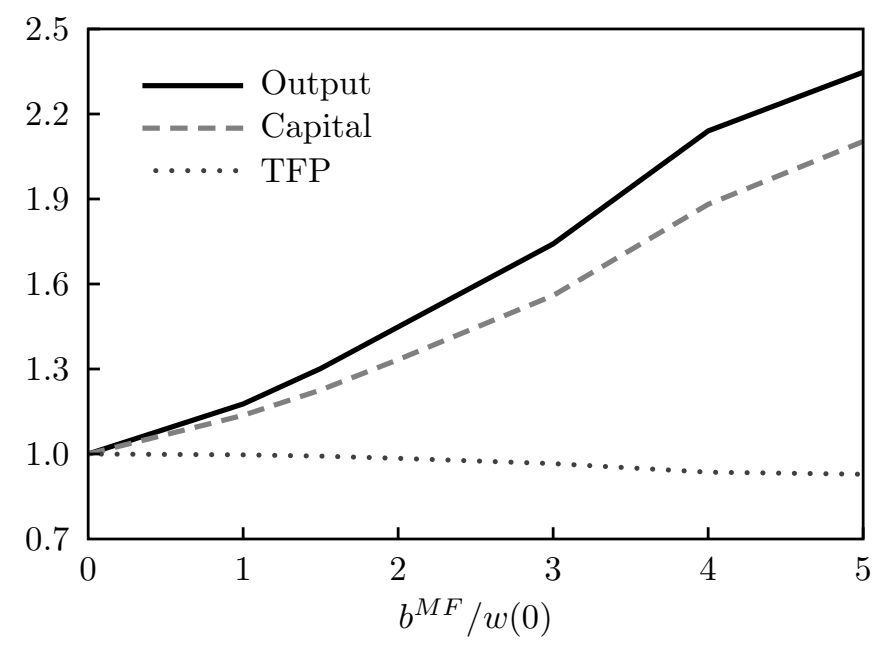

Fig. 3: Long-Run Aggregate Implications in Partial Equilibrium

entrepreneurs than in the short run. Some marginal entrepreneurs need to save up to start their business even with microfinance, and their entry is not captured in the short run. In addition, with the economy now wealthier as a whole, there are more of the wealthy lowability entrepreneurs in the stationary equilibrium. Such low-ability entrepreneurs would have chosen to be workers were it not for microfinance. Consequently, there is an added, but small, negative effect on TFP in the long run through the extensive margin. ${ }^{23}$

We now contrast these long-run PE results with the long-run GE results. Unlike in PE, aggregate saving and investment decisions must coincide in GE. Of course, labor markets must clear.
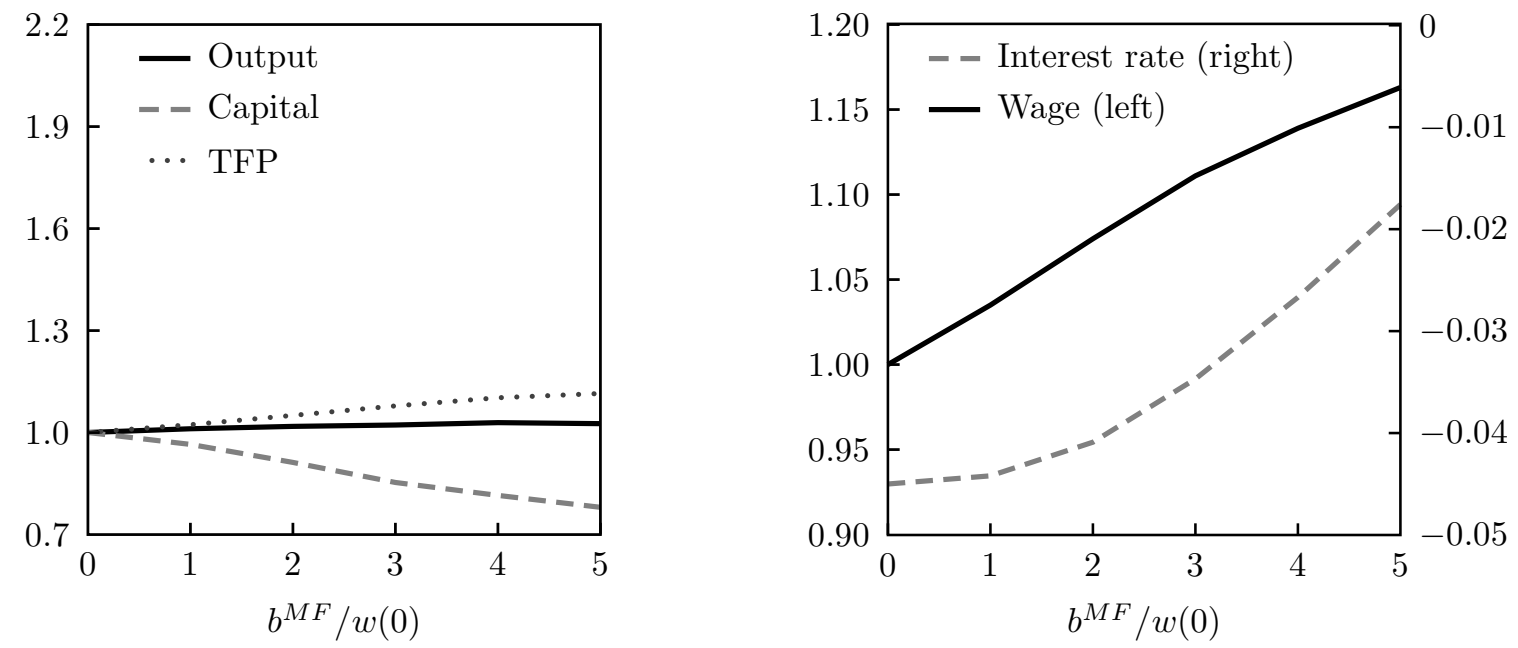

Fig. 4: Long-Run Impact of Microfinance in General Equilibrium

\footnotetext{
${ }^{23} \mathrm{As} b^{M F}$ goes from 0 to $5 w(0)$, the fraction of the population who are entrepreneurs goes from 0.12 to 0.71 in the long run - it goes to 0.60 in the short run (right panel, Figure 1). Even in the long run, the PE economy with microfinance uses workers and capital inputs from outside. When these factor payments are netted out, the income of the population is 33 percent higher with $b^{M F}=5 w(0)$ than with $b^{M F}=0$.
} 
Figure 4 shows the importance of GE considerations for understanding the long-run aggregate impacts of microfinance. In the left panel, we plot the impacts on aggregate output, capital, and TFP. They are starkly different from the PE results of Figure 3. First, capital falls precipitously with the microfinance credit limit in the long-run general equilibrium, by 6 percent for $b^{M F}=1.5 w(0)$ and 23 percent for $b^{M F}=5 w(0)$. Second, TFP is now positively affected by microfinance, by 4 percent for $b^{M F}=1.5 w(0)$ and 12 percent for $b^{M F}=5 w(0)$. Finally, the TFP gains together with the lower capital stock have a net effect on output that is positive but relatively small: 1.5 percent for $b^{M F}=1.5 w(0)$ and 2.5 percent for $b^{M F}=5 w(0)$.

In the right panel of Figure 4, we see that equilibrium interest rates (dashed line) and wages (solid line) rise with $b^{M F}$. The higher interest rate is partly the result of microfinance directly increasing demand for capital, but it is mainly because of microfinance depressing aggregate saving. The increase in wage reflects both a reduction in the supply of workers - as more individuals enter into entrepreneurship - and the increased demand for workers through better selection into entrepreneurship and better capital allocation among entrepreneurs.

We now provide detailed explanations for the GE effects on TFP and capital accumulation in turn.

Effect on TFP In the left panel of Figure 5, we decompose the increase in TFP (solid line) in terms of the intensive (dashed line) and the extensive (dotted line) margins.

As in PE, microfinance improves the allocation of capital among active entrepreneurs, as it relaxes the credit constraints of those who have high marginal product of capital $(k$ efficiency). In PE, the negative effect along the extensive margin dominated this positive effect. This does not happen in GE, and the extensive margin actually contributes to the TFP gains. Microfinance does increase the number of entrepreneurs as a fraction of the population even in GE, by 3 percentage points for $b^{M F}=1.5 w(0)$ and 8 percentage points for $b^{M F}=$ $5 w(0)$, although the magnitudes are much smaller than in PE-the corresponding numbers in the long-run PE case are 9 and 59. This is because, in GE, the price of production factors rises with microfinance, as does the opportunity cost of becoming an entrepreneur, i.e., wage, effectively deterring the entry of the more marginal entrepreneurs. Furthermore, the higher factor prices also cause the exit of untalented-but-rich entrepreneurs. In spite of the overall increase in the number of entrepreneurs, the average ability of active entrepreneurs actually increases modestly, as shown by the dotted line lying above 1 . Nevertheless, especially for large values of $b^{M F}$, it is the allocative efficiency along the intensive margin that accounts for almost all the TFP gains from microfinance. 

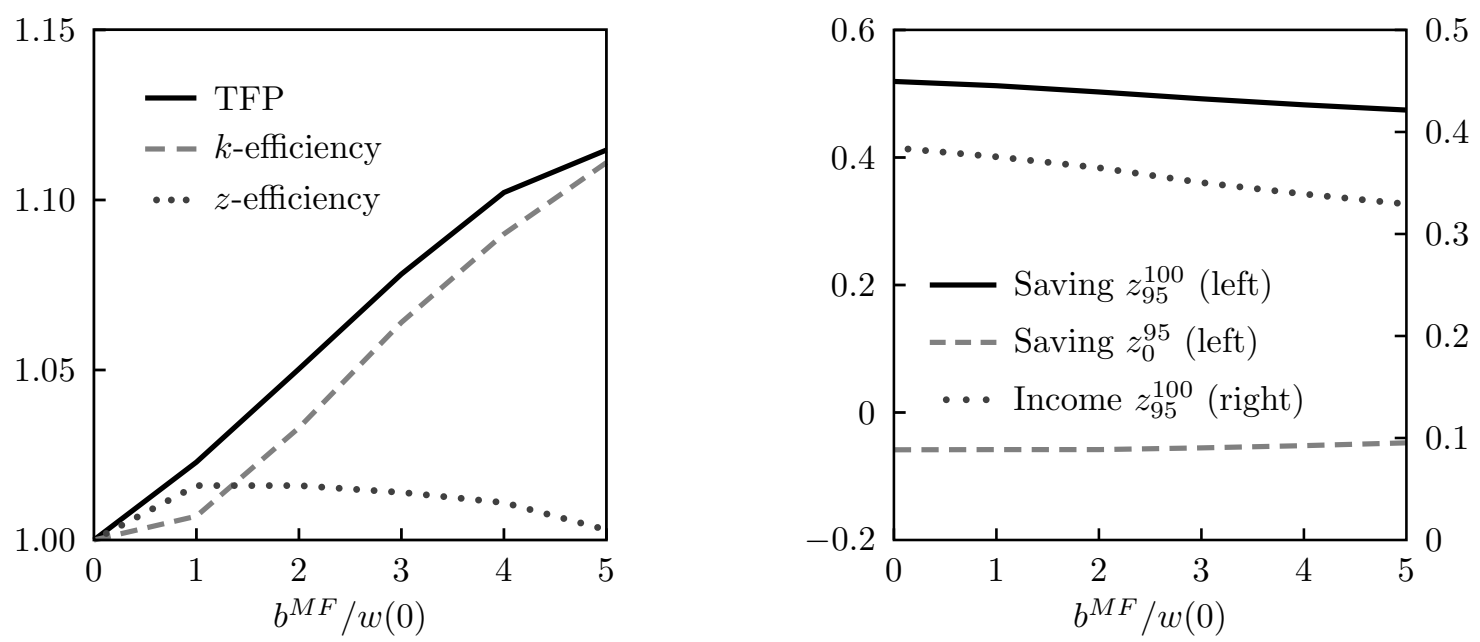

Fig. 5: Decomposition of the Impact of Microfinance in General Equilibrium

Effect on Capital Accumulation We find that the substantial negative impact of microfinance on aggregate capital accumulation in Figure 4 is driven by the redistributive effects of microfinance in general equilibrium.

In the model, individuals with high entrepreneurial ability have high saving rates. There are two reasons. First, given the credit constraints, they derive collateral services from their wealth (i.e., more wealth allows them to produce closer to the efficient scale): For a constrained entrepreneur, his returns to saving can vastly exceed the market interest rate. Second, given the stochastic nature of the entrepreneurial talent, they save for the periods/states in which they will not be as talented and will not generate as much income. In the right panel of Figure 5, the average saving rate of those belonging to the top 5 percentiles (denoted with $z_{95}^{100}$ ) of the ability distribution is shown with a solid line (left scale). This is much higher than the average saving rate of the rest (i.e., those in the bottom 95 percentiles of the ability distribution, denoted with $z_{0}^{95}$ ), which is in fact negative (dashed line).

Those in the latter group mostly choose to be workers, who do not have a self-financing motive. In addition, our model specification is such that one's earnings are bounded from below by the market wage. Therefore, workers do not have any reason to save from the permanent-income perspective: Their earnings will either remain the same or go up in the future. This latter group also includes marginal-ability entrepreneurs. These marginal entrepreneurs clearly have higher saving rates than the workers, because they at least have some self-financing motive for their businesses as well as some permanent-income saving motive since their income may fall in the future. However, compared to those in the top 5 percentiles, their efficient scale is much smaller, and their future earnings are not expected to fall by as much. Overall, their saving rate is far lower than that of the top ability group. 
Note that microfinance with generous credit limits promotes the entry of such marginal entrepreneurs. As shown in the right panel of Figure 5, the income share of the bottom 95-percent talent group increases with $b^{M F}$ — and the income share of the top-talent group declines as shown by the dotted line-because the marginal entrepreneurs now earn more than what they would have earned as a worker, and the aggregate labor income share of workers is constant at $\theta$ in the model. ${ }^{24}$ On the other hand, the income of the top ability group falls: They are mostly entrepreneurs, and their profits shrink as the factor prices increase because of microfinance.

In summary, the income share of those with lower saving rates increases with $b^{M F}$. The aggregate saving rate is the income-weighted average of individual saving rates, and hence microfinance reduces aggregate saving and the steady-state capital stock.

We also note that the saving rate of the top ability group also decreases slightly with $b^{M F}$. There are three reasons for this. First, higher wage and capital rental rate imply lower profits, which in turn mean lower returns to saving for constrained (i.e., talented but poor) entrepreneurs. Second, with higher earnings for marginal-ability individuals, the future earnings of the top-ability group are now expected to fall by less. That is, without microfinance, you either maintain your talent or become a worker in the next period. With generous $b^{M F}$, you could in the next period maintain your talent, become a worker, or become a marginal entrepreneur who earns more than a worker. Therefore, the permanent-income saving motive is weaker with high $b^{M F}$. Finally, with a higher wage and lower entrepreneurial profits for high-ability individuals, the distribution of earnings is now compressed because of microfinance. Holding other things equal, this leads to less precautionary saving.

\subsection{Distribution of Welfare Gains from Microfinance}

Our analysis so far emphasizes that microfinance has heterogeneous impacts, and that the full extent of its effects need to be traced through rich GE considerations. We now explore the distribution of the welfare consequences of microfinance.

In Figure 6, we present the welfare impact of microfinance across the marginal distributions of entrepreneurial ability (left panel) and wealth (right panel) in the initial steady state. We consider both the partial equilibrium (dashed line) and the general equilibrium (solid line), and highlight their differences. We measure the welfare impact as the fraction of consumption an individual of a given ability (integrating out wealth, left panel) or wealth (integrating out ability, right panel) is willing to give up every period in order to have access

\footnotetext{
${ }^{24}$ The entry of marginal entrepreneurs, as a compositional effect, also explains why the average saving rate of the bottom 95-percent talent group increases slightly with $b^{M F}$ (dashed line): The marginal entrepreneurs have higher saving rates than workers, and there are now more entrepreneurs and fewer workers in this $z_{0}^{95}$ group.
} 

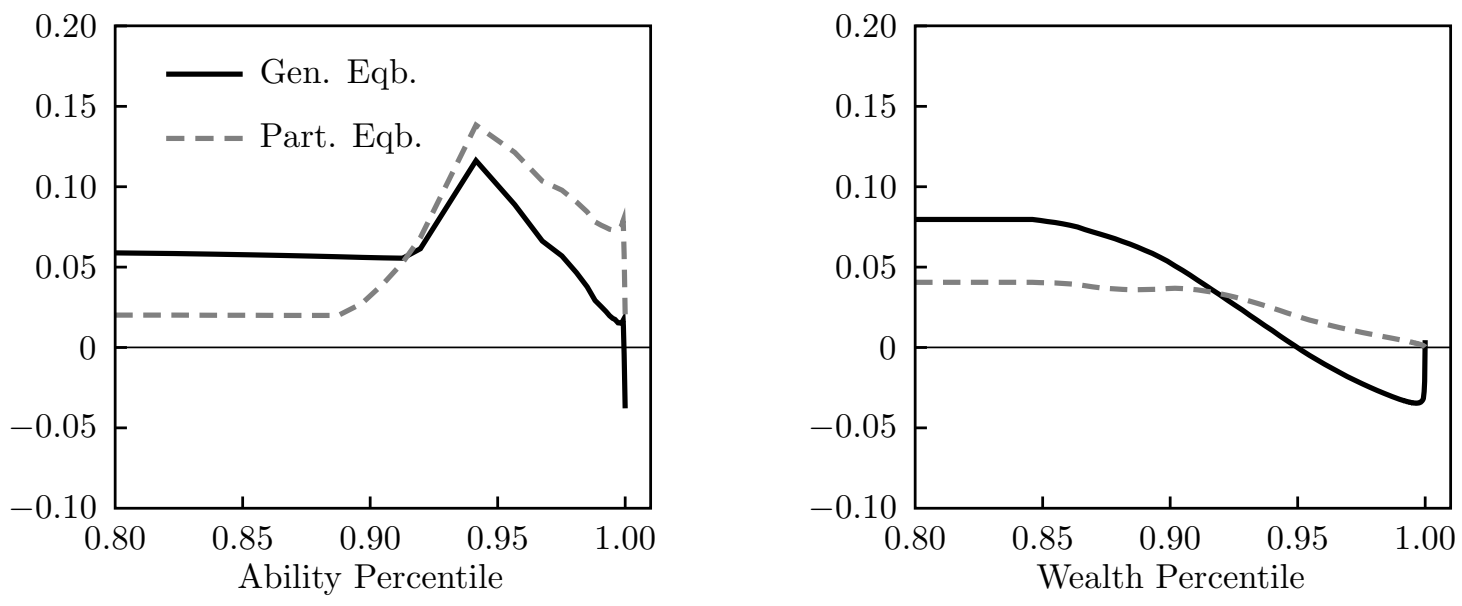

Fig. 6: Welfare Gains of Microfinance with $b^{M F}=1.5 w(0)$

to the microfinance program with $b^{M F}=1.5 w(0)$. Thus, a positive number means welfare gains and a negative number implies welfare loss. Our calculations properly take into account the transitional dynamics following the introduction of microfinance.

Two clear messages emerge from this figure. First, in the left panel, the large spike among relatively high-ability individuals shows who gains the most from microfinance: marginal entrepreneurs. Microfinance does not directly affect those who are too unproductive to become entrepreneurs, and at the same time it is too small to directly affect the business of the most talented and rich entrepreneurs. For marginal entrepreneurs, however, their wealth and the scale of operation are small enough that microfinance has a meaningful direct impact. ${ }^{25}$ Second, in the right panel, consistent with the conventional narratives, microfinance has a large positive impact on the poor, i.e., individuals with low wealth.

Another important lesson is that GE considerations are key to fully understand the distributional impact of microfinance. For instance, a PE analysis would lead to the conclusion that the least talented individuals would be only slightly affected, and that the most talented would be among those most benefiting from microfinance (left panel). ${ }^{26}$ However, when the increase in the equilibrium wage is accounted for, this inference is reversed. Individuals with low entrepreneurial ability, who choose to be workers, experience an additional welfare gain over PE in the order of 4 percent of permanent consumption. On the other hand, the most talented can be made worse-off by microfinance, because their profits are now reduced by the higher equilibrium wage. This can be seen more clearly in the right panel. Indeed, the higher factor prices lead to a welfare loss for the richest 5 percent of the population, who

\footnotetext{
${ }^{25}$ Consider the PE case where prices are not affected by microfinance. It may be puzzling that even the least talented individuals gain from microfinance (dashed line, left panel), although their occupation choice is not affected by it. This is because these individuals will draw a higher ability with some probability in the future, at which point they will directly benefit from microfinance.

${ }^{26}$ Note that no one can be made worse off by microfinance in PE.
} 
tend to be entrepreneurs. ${ }^{27}$

In summary, we have shown the importance of GE considerations for the distributional and welfare implications of economy-wide microfinance.

\subsection{Extensions}

We explore three extensions to the baseline GE model. The first is a small open economy, where wage effects still operate but the interest rate is held constant at the initial level. The second extension introduces an idiosyncratic shock to labor supply that effectively forces individuals, even those with little capital and ability, into entrepreneurship. This captures the idea of undercapitalized, low-ability entrepreneurs with few labor market alternatives, who make up a large fraction of the self-employed in less developed economies. The third extension introduces a large-scale sector that requires a large fixed cost of production. This ushers in another GE effect through the relative price between the large-scale and the smallscale sectors. We find that microfinance plays an important role in how resources (capital, labor, and entrepreneurial talent) are allocated between the two sectors.

\subsubsection{Small Open Economy}

The small open economy we consider differs from the benchmark GE analysis in that we fix the interest rate at its initial value. Relative to our PE analysis, it is different because the wage adjusts to clear the labor market within the economy. This exercise is meant to capture a situation where capital is brought into the economy from outside, for example, by an international NGO.

Perhaps surprising, while the direct effect of the microfinance innovation is to increase capital demand, the resulting higher wage suppresses capital demand in the long run, even though capital is supplied from outside the economy perfectly elastically at the fixed interest rate. The decrease in aggregate capital, although less than in the closed economy, is still sizable. With microfinance credit limits of 2 to 3 times the normalizing wage, the long-run capital stock declines by 5 to 9 percent relative to the initial steady state.

Note that investment and saving decisions are still connected, even though we are making the small open economy assumption. The connection is in the form of the collateral constraint, because an entrepreneur's asset level puts bounds on the amount of capital he can use for production. As such, an explanation of the capital stock decline requires an explanation of the decline in aggregate saving with microfinance. Indeed, the total financial

\footnotetext{
${ }^{27}$ In addition, while barely visible in the right panel, some extremely wealthy individuals are actually better off with microfinance and the resulting higher factor prices: For them, rental income, which increases with the interest rate, is the main income source.
} 
wealth of the economy declines in the long run by more than the capital stock-by 10 to 17 percent relative to the initial steady state, for microfinance credit limits of 2 to 3 times the normalizing wage.

The reasons for the lower aggregate saving are the same as in Section 4.1. Most important, microfinance, through higher wages, redistributes income from high-ability individuals with high saving rates to low-ability individuals - especially marginal entrepreneurs - with low saving rates. In addition, the high-ability individuals' saving rate declines with microfinance, because the returns to saving for constrained entrepreneurs are now lower given the low profits, and also because the compressed earnings distribution (i.e., higher wages and lower profits) implies less permanent-income saving and precautionary saving.

The long-run impact of microfinance on TFP in this extension is smaller than in GE. At $b^{M F}=5 w(0)$, the long-run TFP gains are 7 percent, while it is 11 percent in GE. TFP rises by less here because there is no increase in the interest rate - and hence the rental rate of capital - that discourages the entry of the more marginal entrepreneurs: The fraction of entrepreneurs in the population is higher than in GE by 4 percentage points, and the average ability of active entrepreneurs is correspondingly lower. That is, there is more negative effect on TFP at the extensive margin than in the GE case.

Overall, the impact on aggregate output is very similar to that in GE. With $b^{M F}=5 w(0)$, output (GDP) increases by only 3 percent in the long run, as the positive impact on TFP and the negative impact on capital cancel each other.

\subsubsection{Market Labor Shock}

Self-employment rates tend to be high in less developed countries, and these self-employments are partly a result of the lack of labor market opportunities. To capture this idea, in this extension we add stochastic labor endowment to the benchmark model. To be specific, individuals now draw a vector $\mathbf{z} \equiv\{z, \ell\}$, where $z$ is the entrepreneurial ability and $\ell$ is the productivity as a worker. With probability $1-\chi, \ell=1$, and the individual's occupation choice set is the same as in the benchmark model. However, with probability $\chi, \ell=0$, and the individual is effectively forced into entrepreneurship, since he has no labor to supply to the labor market as a worker. We assume that the $\ell$-shock is independent of the $z$-shock, and that the two are equally persistent. We pick $\chi=0.22$ so that the self-employment rate in the stationary equilibrium of this modified model matches the non-rural self-employment rate of 35 percent in the 2004-05 National Sample Survey of India. ${ }^{28}$ The model now generates a large mass of poor, low-ability entrepreneurs, who earn less than the market wage.

We then explore the long-run GE impacts of microfinance in this extension. The results

\footnotetext{
${ }^{28}$ All other parameter values are left unchanged from the benchmark values of Section 3.1.
} 
differ starkly from the baseline results along a few dimensions. For example, with low levels of $b^{M F}$ (up to 3 times the normalizing wage), output and wage actually fall with microfinance. The most important impact of microfinance here is on the aggregate saving. For this range of $b^{M F}$, most "forced" entrepreneurs max out the microfinance limit, pushing up the interest rate - and hence the capital rental rate - by substantially more than in the benchmark GE case. This also implies that the microfinance innovation leads to substantially higher take-up rates and a larger increase in the external finance to GDP ratio than in the benchmark. The forced entrepreneurs, who tend to have low productivity, now reduce their saving rates drastically, because the access to uncollateralized financing implies that they need not accumulate collateral for production any more. ${ }^{29}$ Those with marginal entrepreneurial productivity and labor market opportunities also cut their saving rates substantially, because now they will choose to be workers, because of the higher capital rental rate, and hence do not need collateral. In addition, through the higher capital rental rate, microfinance redistributes income from high-savers (i.e., high-ability entrepreneurs) to low-savers, even more massively than in the benchmark GE case. Overall, aggregate capital declines sharply, by 18 percent for the microfinance loan size that is one and a half times the annual wage. Microfinance does have a positive impact of TFP, but it pales in comparison with the negative effect on aggregate capital. As a result, aggregate output and the wage actually fall below their levels in the no-microfinance equilibrium.

With large enough microfinance (e.g., $b^{M F}$ more than 3 times the normalizing wage), the marginal entrepreneurs and the most talented entrepreneurs also directly benefit from microfinance, and the positive impact of microfinance on TFP dominates the negative impact on capital accumulation. As a result, output and wages are higher than in the no-microfinance case. The magnitude of the increase in output is still smaller than in our benchmark case without the market labor shock, however.

In terms of welfare, the lowest-ability forced entrepreneurs now gain the most from microfinance. Those who choose to be workers gain less or even lose out in terms of wages, but are still better off in expected utility terms, since they will also benefit from microfinance when hit with the market labor shock in the future.

\subsubsection{Large-Scale Sector}

Large-scale establishments dominate certain sectors such as manufacturing, investment goods production in particular, and less developed countries tend to have lower relative productivity

\footnotetext{
${ }^{29}$ This is consistent with the empirical evidence of de Mel et al. (2008, 2009) and Fafchamps et al. (2010), who find that grants to low-wealth female entrepreneurs, likely forced into entrepreneurship because of labor market frictions, yielded substantially smaller increases in profits and capital.
} 
and higher relative prices in these sectors (Buera et al., 2011). In a multi-sector model, microfinance, although it is not explicitly sector-specific, may affect a third price margin, the relative price between large-scale and small-scale sectors.

Following Buera et al., we introduce a second sector with a production technology that requires a fixed $\operatorname{cost} \kappa$ for operation each period. Individuals now draw a stochastic vector $\mathbf{z} \equiv\left\{z, z_{L}\right\}$, where $z_{L}$, the productivity in the large-scale sector, is distributed identically but independently of the small-scale sector productivity, $z$. Individuals choose between being a worker and operating a technology in either sector. Quantitatively, we use the calibration of Buera et al., and in particular set $\kappa=4.68$ to match the observed difference in average establishment size between manufacturing and services. We assume that all capital is produced in the large-scale sector. In addition, for now, we assume that the two goods enter a CES utility function with the unitary elasticity of substitution between them.
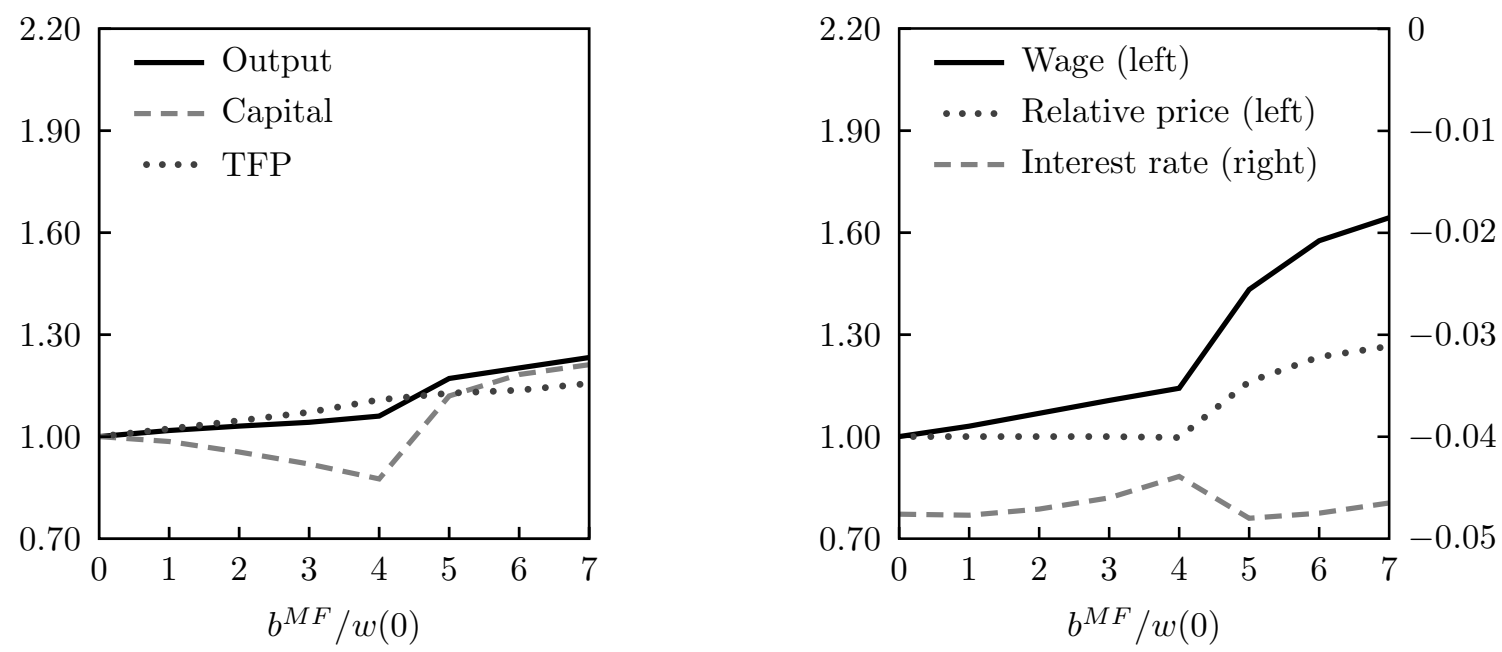

Fig. 7: Aggregate Impacts in Two-Sector Model

Figure 7 shows the GE implications of microfinance in this two-sector model in the long run. The relative price is equal to the price of the small-scale sector output, since we assume that the large-scale sector output is the numeraire. Output and TFP are constructed using constant relative prices. In the figure, all variables except the interest rate are normalized by their respective values in the equilibrium without microfinance.

The effects of microfinance are strikingly non-linear, and even non-monotone for certain variables. For moderate levels of microfinance, the model behaves very similarly to the onesector model, although the relative price of the small-scale sector falls somewhat, because financial frictions in this sector are more easily alleviated by microfinance and there is more entry into this sector. It is at higher levels of guaranteed credit, those more than 4 times the normalizing wage, that the two-sector model shows striking differences. Here, microfinance dramatically increases wages and output because it raises TFP and capital accumulation, 
even in GE. The threshold for this change lies where the amount of guaranteed credit is sufficient to induce individuals with the highest ability in the large-scale sector to become entrepreneurs even if they have no wealth. In this region, the GE effect through the relative price drives the results. Aggregate capital increases because the increase in the relative price of small-scale output is equivalent to a decrease in the relative price of capital: Each unit of forgone consumption now yields more physical capital.

Finally, when we assume smaller substitutability between the goods produced by the large-scale and the small-scale sectors, microfinance with small loan sizes increases even more significantly entrepreneurs' entry into the small-scale sector but not the large-scale sector, substantially pushing down the relative price of the small-scale sector good. This partially offsets the wage increase caused by the marginal entrepreneurs selecting out of the labor supply, and more negatively affects capital accumulation, because investment goods are now relatively more expensive. The same nonlinear effects of microfinance emerge, once the loan size reaches a certain threshold.

\section{Concluding Remarks}

Microfinance programs are growing around the world, and indeed in some countries, the scale of microfinance is approaching levels where general equilibrium effects should be reckoned with. This paper shows that such general equilibrium considerations are qualitatively and quantitatively important for the evaluation of the aggregate and distributional impacts of economy-wide microfinance. In particular, the increase in wages in general equilibrium has a strong redistributive effect. This leads to substantially smaller aggregate capital stock in contrast to the predictions from partial equilibrium analyses. At the same time, it reinforces the positive welfare effects of microfinance on low-ability, low-wealth individuals.

We conjecture that our results may be applicable even to local-level microfinance interventions. In many developing countries, local markets are essentially segmented - see, for example, Townsend (1995) — because of high transportation/trade costs or information frictions. In such environments, even moderately-sized microfinance interventions may exhibit the important general equilibrium effects shown in the paper. 


\section{Appendix: TFP Decomposition}

In this appendix, we derive the decomposition of TFP used in Figures 1 and 5 . Using the optimal choice of labor input, $l(a, z)=\left(z \theta k(a, z)^{\alpha} / w\right)^{1 /(1-\theta)}$, we can write aggregate output as:

$$
Y=(\theta / w)^{\frac{\theta}{1-\theta}} \int_{\{(a, z): o(a, z)=E\}} z^{\frac{1}{1-\theta}} k(a, z)^{\frac{\alpha}{1-\theta}} G(d a, d z) .
$$

We denote the aggregate labor input by $L \equiv \int_{\{o(a, z)=E\}} l(a, z) G(d a, d z)$ and the aggregate total labor input by $N=L+N^{E}$, i.e., labor plus the un-weighted entrepreneurial input with $N^{E} \equiv \int_{\{o(a, z)=E\}} G(d a, d z)$. Also, the aggregate capital input is $K$, and the share of capital employed by an individual entrepreneurs is defined as $\varkappa(a, z)=k(a, z) / K$. We can now rewrite aggregate output as:

$$
Y=\frac{\left[\int_{\{(a, z): o(a, z)=E\}^{2}} z^{\frac{1}{1-\theta}} \varkappa(a, z)^{\frac{\alpha}{1-\theta}} G(d a, d z)\right]^{1-\theta}}{N^{1-\alpha-\theta}}\left(\frac{L}{N}\right)^{\theta} K^{\alpha} N^{1-\alpha} .
$$

We define TFP as output net of the capital and broad labor inputs, raised to their respected income elasticities, $\alpha$ and $1-\alpha$,

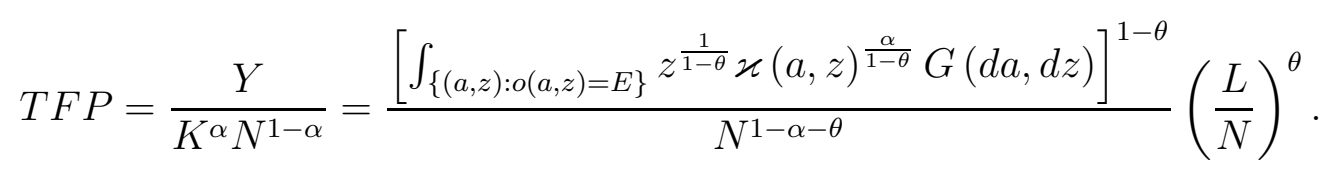

We view this to be the measurement of TFP that is closest to the one used in development accounting exercises.

In addition, we define the " $k$-efficient" TFP, $T F P^{k f}$, as the hypothetical value of TFP attained if capital were to be efficiently allocated among existing entrepreneurs to equalize their marginal product. When capital is efficiently allocated across the existing entrepreneurs, the fraction of total capital employed by one entrepreneur of ability $z$ is:

$$
\varkappa^{k f}(z)=\frac{z^{\frac{1}{1-\alpha-\theta}}}{\int_{\{(a, z): o(a, z)=E\}^{2}} z^{\frac{1}{1-\alpha-\theta}} G(d a, d z)},
$$

and the aggregate output under this efficient allocation of capital, $Y^{k f}$, is obtained by substituting (8) into (7). We then formally write out the $k$-efficient TFP,

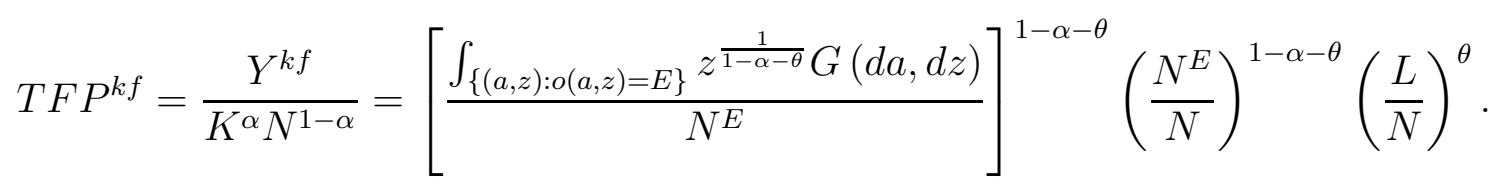

Note that this measure is only a function of a geometrically-weighted average of active entrepreneurs' talent and the fraction of entrepreneurs and workers in the population. 
Using the $k$-efficient TFP measure, we can decompose the change in TFP caused by the introduction of microfinance in terms of the allocation of entrepreneurs at the extensive margin ( $z$-efficiency) and the allocation of capital across active entrepreneurs ( $k$-efficiency). Here, $T F P\left(b^{M F}\right)$ is the realized TFP with microfinance of a given $b^{M F}$, and $T F P(0)$ is the TFP in the initial equilibrium without microfinance.

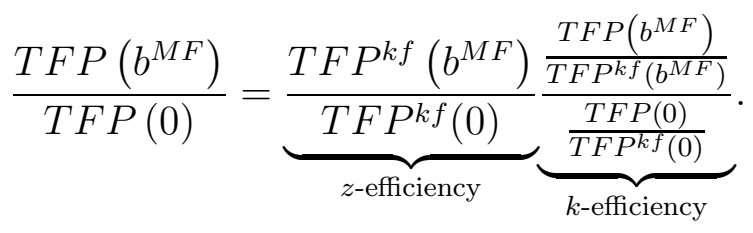

The z-efficiency term captures the TFP change from microfinance that is driven purely by the reallocation of entrepreneurial talent at the extensive margin. We obtain this counterfactual measure by calculating the change in TFP that would occur in a world where capital is allocated efficiently among active entrepreneurs with and without microfinance, $T F P^{k f}\left(b^{M F}\right) / T F P^{k f}(0)$. In computing $T F P^{k f}\left(b^{M F}\right)$ and $T F P^{k f}(0)$, capital is efficiently allocated by definition, and hence they can be different only if the set of entrepreneurs operating technologies is affected by microfinance. Note that z-efficiency below 1 implies a worse selection into entrepreneurship through microfinance, and the other way around for $z$-efficiency above 1 . On the other hand, the $k$-efficiency term reflects the change in the allocative efficiency of capital at the intensive margin, and is calculated as the residual change in TFP necessary to account for the overall change in TFP. 


\section{References}

Aghion, P. And P. Bolton (1997): "A Theory of Trickle-Down Growth and Development," Review of Economic Studies, 64, 151-172.

Ahlin, C. And N. Jiang (2008): "Can Micro-Credit Bring Development?" Journal of Development Economics, 86, 1-21.

Ahlin, C. And R. M. Townsend (2007): "Using Repayment Data to Test Across Models of Joint Liability Lending," Economic Journal, 117, F11-51.

Amaral, P. And E. Quintin (2010): "Financial Intermediation and Economic Development: A Quantitative Assessment," International Economic Review, 51, 785-811.

Armendariz, B. And J. Morduch (2005): The Economics of Microfinance, Cambridge, MA: MIT Press.

Attanasio, O., B. Augsburg, R. De Haas, E. Fitzsimons, and H. Harmgart (2011): "Group Lending or Individual Lending? Evidence from a Randomised Field Experiment in Mongolia," Working Papers 136, European Bank for Reconstruction and Development.

Banerjee, A. V. And E. Duflo (2008): "Do Firms Want to Borrow More? Testing Creit Constraints Using a Directed Lending Program," Manuscript, Massachusetts Institute of Technology.

Banerjee, A. V., E. Duflo, R. Glennerster, and C. Kinnan (2009): "The Miracle of Microfinance? Evidence from a Randomized Evaluation," Manuscript, Massachusetts Institute of Technology.

Banerjee, A. V. and A. F. Newman (1993): "Occupational Choice and the Process of Development," Journal of Political Economy, 101, 274-298.

Beck, T., A. DemirgüÇ-Kunt, And R. Levine (2000): "A New Database on the Structure and Development of the Financial Sector," World Bank Economic Review, 14, 597-605.

Besley, T. and S. Coate (1995): "Group Lending, Repayment Incentives and Social Collateral," Journal of Development Economics, 46, 1-18.

Buehren, N. And K. Richter (2010): "Microfinance on a Large-Scale: Evidence from the Thai Village Fund," Tech. rep., University College of London.

Buera, F. J. (2009): "A Dynamic Model of Entrepreneurship with Borrowing Constraints: Theory and Evidence," Annals of Finance, 5, 443-464. 
Buera, F. J., J. P. Kaboski, And Y. Shin (2011): "Finance and Development: A Tale of Two Sectors," American Economic Review, 101, 1964-2002.

Buera, F. J. And Y. Shin (2010): "Financial Frictions and the Persistence of History: A Quantitative Exploration," Working Paper 16400, National Bureau of Economic Research.

Carpena, F., S. Cole, J. Shapiro, and B. Zia (2010): "Liability Structure in SmallScale Finance : Evidence from a Natural Experiment," Policy Research Working Paper Series 5427, The World Bank.

Crépon, B., F. Devoto, E. Duflo, and E. Parienté (2011): "Impact of Microcredit in Rural Areas of Morocco: Evidence from a Randomized Evaluation," Manuscript.

de Mel, S., D. McKenzie, and C. Woodruff (2008): "Returns to Capital in Microenterprises: Evidence from a Field Experiment," Quarterly Journal of Economics, 123, $1329-1372$.

(2009): "Are Women More Credit Constrained? Experimental Evidence on Gender and Microenterprise Returns," American Economic Journal: Applied Economics, 1, 1-32.

Erosa, A. And A. Hidalgo Cabrillana (2008): "On Finance as a Theory of TFP, Cross-Industry Productivity Differences, and Economic Rents," International Economic Review, 49, 437-473.

Fafchamps, M., D. McKenzie, S. Quinn, And C. Woodruff (2010): "Using PDA Consistency Checks to Increase the Precision of Profits and Sales Measurement in Panels," CSAE Working Paper 2010-19, Centre for the Study of African Economies, University of Oxford.

Field, E. AND R. PANDe (2008): "Repayment Frequency and Default in Microfinance: Evidence From India," Journal of the European Economic Association, 6, 501-509.

Fischer, G. And M. Ghatak (2010): "Repayment Frequency in Microfinance Contracts with Present-Biased Borrowers," Economic Organisation and Public Policy Discussion Papers Series 021, London School of Economics.

Gentry, W. M. and R. G. Hubbard (2000): "Entrepreneurship and Household Saving," NBER Working Papers 7894, National Bureau of Economic Research, Inc.

Gine, X. And D. Karlan (2010): "Group versus Individual Liability: Long Term Evidence from Philippine Microcredit Lending Groups," Manuscript, Yale University, New Haven.

Giné, X. And R. M. Townsend (2004): "Evaluation of Financial Liberalization: A General Equilibrium Model with Constrained Occupation Choice," Journal of Development Economics, 74, 269-307. 
Hurst, E. AND A. Lusardi (2004): "Liquidity Constraints, Household Wealth, and Entrepreneurship," Journal of Political Economy, 112, 319-347.

Jain, S. And G. Mansuri (2003): "A Little at a Time: The Use of Regularly Scheduled Repayments in Microfinance Programs," Journal of Development Economics, 72, 253-279.

Jeong, H. And R. M. Townsend (2007): "Sources of TFP Growth: Occupational Choice and Financial Deepening," Economic Theory, 32, 197-221.

(2008): "Growth and Inequality: Model Evaluation Based on an EstimationCalibration Strategy," Macroeconomic Dynamics, 12, 231-284.

Kaboski, J. and R. Townsend (2005): "Policies and Impact: An Analysis of VillageLevel Microfinance Institutions," Journal of the European Economic Association, 3, 1-50.

(2011): "A Structural Evaluation of a Large-Scale Quasi-Experimental Microfinance Initiative," Econometrica, 79, 1357-1406.

_ (2012): "The Impact of Credit on Village Economies," American Economic Journal: Applied Economics, Forthcoming.

Karlan, D. and J. Zinman (2010): "Expanding Microenterprise Credit Access: Using Randomized Supply Decisions to Estimate the Impacts in Manila," Manuscript, Yale University.

Lloyd-Ellis, H. ANd D. Bernhardt (2000): "Enterprise, Inequality and Economic Development," Review of Economic Studies, 67, 147-168.

Paulson, A. L. And R. M. Townsend (2004): "Entrepreneurship and Financial Constraints in Thailand," Journal of Corporate Finance, 10, 229-262.

Pawasutipaisit, A. And R. M. Townsend (2010): "Wealth Accumulation and Factors Accounting for Success," Manuscript, Massachusetts Institute of Technology.

Pitt, M. M. And S. R. Khandker (1998): "The Impact of Group-Based Credit Programs on Poor Households in Bangladesh: Does the Gender of Participants Matter?" Journal of Political Economy, 106, 958996.

QUADRINI, V. (1999): "The Importance of Entrepreneurship for Wealth Concentration and Mobility," Review of Income and Wealth, 45, 1-19.

Townsend, R. M. (1995): "Financial Systems in Northern Thai Villages," Quarterly Journal of Economics, 110, 1011-1046. 